\title{
Cdk8 directly regulates glycolysis via phosphorylation of Gcr2
}

Maria J. Aristizabal ${ }^{1,2,3, *}$, Eoghan O'Duibhir ${ }^{4}$, Wim de Jonge ${ }^{4}$, Kristy Dever $^{1}$, Nicole Hawe ${ }^{5}$, Marian Groot Koerkamp ${ }^{4}$, Mariel Brok ${ }^{4}$, Dik van Leenen ${ }^{4}$, Philip Lijnzaad ${ }^{4}$, Michael S. Kobor ${ }^{1}$, Frank C.P. Holstege ${ }^{4}$, Ivan Sadowski ${ }^{5}$

${ }^{1}$ Centre for Molecular Medicine and Therapeutics, BC Children's Hospital Research Institute, Department of Medical Genetics, University of British Columbia, Vancouver, British Columbia V5Z 4H4, Canada

${ }^{2}$ Department of Ecology and Evolutionary Biology, University of Toronto, 25 Willcocks Street, Toronto, Ontario M5S 3B2, Canada \& Child and Brain Development Program, Canadian Institute for Advanced Research (CIFAR), 180 Dundas Street West, Suite 1400, Toronto, Canada

${ }^{3}$ Currently in the Department of Biology, Queen's University, Kingston ON K7L 3N6, Canada

${ }^{4}$ Princess Máxima Center for Pediatric Oncology || Heidelberglaan 25| 3584 CS UTRECHT, the Netherlands

${ }^{5}$ Department of Biochemistry and Molecular Biology, Molecular Epigenetics, Life Sciences Institute, University of British Columbia, Vancouver V6T 1Z3, British Columbia, Canada

\footnotetext{
* To whom correspondence should be addressed: maria.aristizabal@queensu.ca
} 


\begin{abstract}
CDK8 encodes an evolutionarily conserved Mediator complex kinase subunit that functions in general and context-specific transcription regulation by phosphorylating core components of the transcription machinery and gene-specific transcription factors. To better understand the role Cdk8 in transcription regulation, we performed high-resolution gene expression time course analysis following nuclear depletion of Cdk8. Focusing on the earliest gene expression alterations revealed dysregulation of genes encoding glycolysis enzymes, suggesting a functional link to Gcr1 and Gcr2, key transcriptional activators of these genes. Consistently, we found that nuclear depletion of Cdk8 altered the mRNA levels of glycolysis genes as well as the promoter occupancy of Gcr2, but not Gcr1. Examination of the Gcr2 protein sequence revealed a putative Cdk8 phosphorylation site at serine 365 , which we confirmed using in vitro and in vivo assays. Importantly, phospho-mutant GCR2 recapitulated the growth and gene expression defects of the GCR2 deletion mutant, effects not observed with a phospho mimetic mutant. As such, our work highlights Gcr2 as a new Cdk8 substrate, revealing that its phosphorylation is critical for the activation of genes encoding glycolysis enzymes.
\end{abstract}

\title{
Keywords:
}

Cdk8, glycolysis, transcription factor, Gcr2, phosphorylation, Mediator complex 


\section{INTRODUCTION}

Cdk8 is a cyclin dependant kinase that together with Cyclin C, Med12 and Med13 forms the kinase submodule of the RNA Polymerase II-associated Mediator complex. Mediator is a conserved transcription co-activator complex required for the response to transcription factors and is likely involved in the transcription of all protein-coding genes (reviewed in (Conaway and Conaway, 2011; Kornberg, 2005).

Despite extensive research, the role of Cdk8 in transcriptional regulation is still enigmatic. Evidence indicates that Cdk8 has both general and gene-specific roles in transcription, and can act as a positive or negative regulator of gene expression in both yeast and metazoan cells. Observations demonstrating an association with the Mediator complex, and genetic links to the carboxy-terminal domain (CTD) of RNA polymerase II (Aristizabal et al., 2013; Kim et al., 1994; Liao et al., 1995), position Cdk8 as a general modulator of transcription. Accordingly, Cdk8 phosphorylates components of the general transcription machinery including the RNA polymerase II CTD (Liao et al., 1995), other Mediator subunits (Hallberg et al., 2004; Liu et al., 2004; Miller et al., 2012; Peppel et al., 2005; Poss et al., 2016), as well as the TATA Binding / TFIID-associated proteins Taf2 and Bdf1 (Liu et al., 2004).

Several lines of evidence also support gene-specific activities for Cdk8. First, in stark contrast to most subunits that make up the Mediator core, genes encoding subunits of the kinase submodule are dispensable for viability in yeast (Hengartner et al., 1995). In fact, mutant alleles of $c d k 8$, cyclin C, med12 or med13 have been identified in over 10 different genetic screens aimed at identifying modulators of specific regulatory processes (Balciunas and Ronne, 1995; Carlson et al., 1984; Li et al., 2005; Surosky et al., 1994; Tabtiang and Herskowitz, 1998). Second, high-throughput gene expression profiling revealed that only a subset of genes were affected upon cdk8 deletion, compared to genome-wide effects observed upon disruption of Mediator core components like MED17 (Holstege et al., 1998; Peppel et al., 2005). Third, multiple gene-specific transcription factors are direct targets of Cdk8 (Chi, 2001; Hirst et al., 1999; Lenssen et al., 2007; Nelson et al., 2003; Raithatha et al., 2011). Amongst these, Gcn4, Ste12 and Phd1 are negatively regulated by Cdk8-dependent phosphorylation, which promotes their proteolytic degradation (Chi, 2001; Nelson et al., 2003; Raithatha et al., 2011; Rosonina et al., 2012). In contrast, Cdk8-dependent phosphorylation of the Gal4 transactivator is required for full induction of GAL gene expression, underscoring both negative and positive effects of Cdk8 on specific gene transcription (Hirst et al., 1999). 
Most of what we know about Cdk8 has emerged from studies in yeast using steady-state perturbation via gene deletion. Knockout of $C D K 8$ in yeast has at least two obvious phenotypic consequences under standard growth conditions, flocculence (Holstege et al., 1998) and reduced growth rate (Hengartner et al., 1995). Flocculence is produced by a differentiated state, known as filamentous or pseudohyphal growth, wherein yeast form elongated cells that remain attached after cell division due to changes in the composition of their cell wall in response to nutrient limitation (reviewed in (Cullen and Sprague, 2012). Accordingly, Cdk8 is known to regulate filamentous growth by phosphorylating the transcription factors Ste12 and Phd1, modulating their stability (Nelson et al., 2003; Raithatha et al., 2011). Slow growth, has the potential to confound the effect of CDK8 deletion on gene expression, an effect that has been observed for other null mutants (O'Duibhir et al., 2014). Thus, assessing a direct role for Cdk8 in gene regulation is complicated by a challenge common to many studies aimed at illuminating molecular mechanisms of transcription regulation, the potential for confounding secondary effects produced by null mutations. These can emerge from downstream events, or exposure of compensatory mechanisms that alter gene expression or result in a particular phenotypic state, including slow growth.

Reduced proliferation of CDK8 null mutants in standard growth media containing glucose indicates that $C D K 8$, although not essential, is required for the most rapid growth of yeast. While these effects likely emerge from defects in specific gene expression programs, they may confound gene expression profiles and mask direct effects of CDK8 in transcription. To separate the effects of slow growth from direct effects of $C D K 8$ function we made use of rapid, non-invasive conditional nuclear depletion of Cdk8 using the "anchor-away" system (Haruki et al., 2008). Examining gene expression changes in high temporal resolution, immediately following Cdk8 nuclear depletion, revealed decreased expression of specific gene subsets, some of which had not been previously associated with Cdk8 function. Analysis of the regulatory regions of these genes pointed to Gcr1 and Gcr2, key transcriptional activators of genes encoding glycolysis enzymes (Uemura and Jigami, 1992a), as potential targets of Cdk8. Examining this relationship further revealed that Cdk8 directly phosphorylated the transcription factor Gcr2, a modification required for growth on glucose containing media and the expression of genes encoding enzymes involved in glycolysis. 


\section{MATERIALS AND METHODS}

\section{Yeast strains and plasmids}

All yeast strains and plasmids used in this study are listed in Table 1 and Table 2. The parental anchor-away strain in the S288C/BY4742 background was described previously (de Jonge et al., 2017).

\section{Cell growth}

Strains were streaked from $-80^{\circ} \mathrm{C}$ stocks onto appropriate selection plates and grown for 3 days. Liquid cultures were inoculated from independent colonies and grown overnight in Synthetic Complete (SC) medium: 2gr/L Drop out mix Complete and 6.71gr/L Yeast Nitrogen Base without AA, Carbohydrate \& w/AS (YNB) from US Biologicals (Swampscott, USA) with 2\% Dglucose. Two cultures each of both parental anchor-away (AA) and Cdk8-AA strains were grown from overnight cultures. For growth rate determination, cells were grown in $1.5 \mathrm{ml}$ of SC media at $30^{\circ} \mathrm{C}$ with shaking at $230 \mathrm{rpm}$ in an automated Infinite 200 incubator (Tecan). For time course experiments and protein isolation, overnight cultures were diluted to an $\mathrm{OD}_{600}$ of $0.15 \mathrm{in} 50 \mathrm{ml}$ of fresh medium and grown in $250 \mathrm{ml}$ Erlenmeyer flasks at $30^{\circ} \mathrm{C}$ with $230 \mathrm{rpm}$ in a shaking incubator to an optical density of 0.6. Rapamycin was added to each of the four cultures giving a final concentration of $7.5 \mu \mathrm{M}$ (time point 0 ). Cultures were sampled for mRNA, flocculence and $\mathrm{OD}_{600}$ measurements at the indicated time points. Throughout the time course, cultures were diluted with fresh SC media containing $7.5 \mu \mathrm{M}$ rapamycin in order to maintain an $\mathrm{OD}_{600}$ of 0.4 to 1.4 , thus avoiding entry into the diauxic shift.

\section{RNA extraction}

Cell were harvested by centrifugation ( $4000 \mathrm{rpm}, 3 \mathrm{~min}$ ) and pellets were immediately frozen in liquid nitrogen. Total RNA was prepared by phenol extraction and cleaned using a customized Sciclone ALH 3000 Workstation. Briefly, frozen cells $\left(-80^{\circ} \mathrm{C}\right)$ were resuspended in $500 \mu$ Acid Phenol Chloroform (Sigma, 5:1, $\mathrm{pH} 4.7$ ), followed by immediate addition of an equal volume of TES-buffer (TES: $10 \mathrm{mM}$ Tris pH 7.5, $10 \mathrm{mM}$ EDTA, 0.5\% SDS). Samples were vortexed vigorously for 20 seconds, incubated in a water bath for 10 minutes at $65^{\circ} \mathrm{C}$ and vortexed vigorously one more time. Samples were then placed in a thermomixer $\left(65^{\circ} \mathrm{C}, 1400 \mathrm{rpm}\right)$ for 50 minutes followed by 20 min of centrifugation ( $\left.4^{\circ} \mathrm{C}, 14000 \mathrm{rpm}\right)$. Phenol extraction was repeated once, followed by a Chloroform:Isoamyl-alcohol (25:1) extraction. RNA was precipitated with Sodium Acetate ( $\mathrm{NaAc} 3 \mathrm{M}, \mathrm{pH} 5.2)$ and ethanol $\left(96 \%,-20^{\circ} \mathrm{C}\right)$. The RNA pellet was washed with 
Ethanol, dissolved in sterile water (MQ), snapfrozen and stored at $-80^{\circ} \mathrm{C}$. All strains were profiled four times from two independently inoculated cultures.

\section{Microarray profiling}

Dual-channel 70-mer oligonucleotide arrays were employed with a common reference wild type RNA. All steps after RNA isolation were automated using robotic liquid handlers. These procedures were first optimized for accuracy (correct fold change (FC)) and precision (reproducible result), using a spiked-in RNA calibration (Bakel and Holstege, 2004). After quality control, normalization (print-tip LOESS; no background correction), and gene specific dye-bias correction (Margaritis et al., 2009) statistical analysis was performed using Limma (Smyth, 2005) for each Cdk8-AA versus the corresponding Parental-AA at the same time point. The reported FC and p-values are an average of the four replicate Cdk8-AA profiles versus the average of four Parental-AA profiles.

\section{Identifying transient gene expression profiles}

Transient expression profiles were identified by correlating the expression profiles of all transcripts in the Cdk8-AA time course to a supervised pre-defined profile. For this the cosine correlation similarity measure was used. A parameter sweep identified the profiles that best fit the data. The parameters represent the time points indicating the start of the peak, the top of the peak (including the width) and when expression returned to Parental-AA. The optimal profiles were identified manually to best fit the data represented in the time course expression profile. The results are robust to small changes in parameters. Transcripts with a correlation better than $\mathrm{R}=0.9$ were considered as part of the cluster.

\section{Motif discovery and analysis}

Putative transcription factor binding motifs were identified for the transient gene expression profiles. The MEME (Multiple Expectation Maximization for Motif Elicitation) (Bailey and Elkan, 1994) algorithm was applied to the sequences encompassing $600 \mathrm{bp}$ upstream of the translation start site of the transient transcripts. Limits for the motifs are set to a 6 basepair minimum and a 20 basepair maximum. Any number of motif repetitions distributed among the sequences was allowed. A third order Markov model was used as background. The most significant motif of each expression profile was submitted to Tomtom for a comparison against a database of known yeast transcription factor binding motifs (Gupta et al., 2007). 


\section{Multiple sequence alignment}

The S. cerevisiae Gcr2 protein sequences was used in a search against the Refseq protein database of all fungal species using Blastp (Altschul, 1997). Standard settings were used including a word size of 3, BLOSSUM62 as substitution matrix and a gap penalty of 11 for opening and 1 for extending a gap within the alignment. Sequences of the best hits for each species were used to generate a multiple sequence alignment using mafft version 7 (Katoh and Standley, 2013). L-INS-i was used together with the BLOSSUM62 substitution matrix, a gap penalty of 1.53 and offset value of 0 .

\section{Chromatin Immunoprecipitation}

ChIP was carried out as previously described (Bakel et al., 2008) with some modifications. In short, $250 \mathrm{~mL}$ of mid-log growing yeast cells $\left(\mathrm{OD}_{595}=0.6\right)$ were cross-linked with $2 \%$ formadehyde for $30 \mathrm{~min}$ at $30^{\circ} \mathrm{C}$, the reaction was quenched with glycine, and cells were collected by centrifugation. All samples were harvested at the same time and OD.

Subsequently, cells were spheroplasted according to the protocol from the Rando lab (Rando, 2010) followed by sonication (Bioruptor, Diagenode: ten cycles, $30 \mathrm{sec}$ on/off, medium setting). $200 \mu \mathrm{L}$ of chromatin extract was incubated with $10 \mu \mathrm{L}$ of anti-V5 beads (Sigma) overnight at $4^{\circ} \mathrm{C}$. After incubation beads were washed twice in FA lysis buffer $(50 \mathrm{mM} \mathrm{HEPES} \mathrm{KOH}$ at $\mathrm{pH}$ 7.5, $150 \mathrm{mM} \mathrm{NaCl}, 1 \mathrm{mM}$ EDTA, 1\% Triton X-100, 0.1\% Na-deoxycholate, 0.1\% SDS), twice with $\mathrm{FA}$ lysis buffer containing $0.5 \mathrm{M} \mathrm{NaCl}$, and twice with $10 \mathrm{mM}$ Tris at pH 8.0, 0.25 mM LiCl, 1 mM EDTA, 0.5\% Nonidet P-40 and 0.5\% Na-deoxycholate. Cross-linking was reversed overnight by incubating at $65^{\circ} \mathrm{C}$ in $150 \mu \mathrm{L} 10 \mathrm{mM}$ Tris- $\mathrm{HCl}(\mathrm{pH} 8.0), 1 \mathrm{mM}$ EDTA, $1 \%$ SDS. Samples were treated with RNAse and proteinase $\mathrm{K}$, and DNA was recovered for further analysis. The ChIP-chip samples were processed as in (Bakel et al., 2008). For ChIP-qPCR, the fold change of Gcr1 and Gcr2 on the PYK1 gene promoter was compared to two control regions (HMR-RT and POL1). Primers are listed in Table 3. RT-qPCR was performed using IQ SYBR Green super mix (BioRad) on a 7900HT fast real time PCR machine (Applied Biosystems). All samples were measured as biological triplicates and technical quadruplicates.

\section{Immunoprecipitation and lambda phosphatase treatment}

Overnight cultures were diluted to $\mathrm{OD}_{600} 0.15$ and grown to an $\mathrm{OD}_{600}$ of 1.5 . For Cdk8 nuclear depletion rapamycin was added to a final concentration of $7.5 \mu \mathrm{M}$ when cell reached $\mathrm{OD}_{600}$ 0.6. Cells were lysed in Lysis buffer (50 mM HEPES (pH 7.5), 150 mM NaCl, 1 mM EDTA, 1\% Triton, $0.1 \%$ sodium deoxycholate, $0.1 \%$ SDS) + Complete protease inhibitor mixture (Roche 
Applied Science) and $0.1 \mathrm{mM} \mathrm{PMSF}$. Fusion proteins were captured using V5 agarose beads (Sigma \# A7345) that were pre-cleared overnight with PBS + 0.1\% BSA. Samples were washed twice with Lysis buffer without phosphatase inhibitors and once with 1X NEBuffer for protein metallophosphatases (50 mM HEPES, 100 mM NaCl, 2 mM DTT, 0.01\% Brij 35, 1 mM MnCl 2 ). Beads were resuspended in 1X NEBuffer for protein metallophosphatases and separated into the indicated treatment groups. 400 units of lambda phosphatase (New England Biolabs, \#P0753) was added as indicated, with all samples incubated $15 \mathrm{~min}$ at $30^{\circ} \mathrm{C}$. Samples were resuspended in Lysis buffer plus 2X SDS buffer and analyzed by SDS-PAGE.

\section{In vitro kinase assays and phosphopeptide analysis}

Direct Gcr2 phosphorylation by Cdk8 was tested in vitro using FLAG-tagged wild type or kinase deficient (cdk8-D290A) Cdk8 recovered from yeast via immunoprecipitation as described previously (Hirst et al., 1999). Cells were lysed in kinase lysis buffer (KLB) (50 mM Tris, 200 mM $\mathrm{NaCl}, 5 \mathrm{mM}$ EDTA, 0.1\% NP-40, and protease inhibitors), and Cdk8 was immunoprecipitated using anti-FLAG M2 beads. The beads were washed twice with KLB followed by two washes with kinase buffer (KB) (10 mM MgCl, $50 \mathrm{mM}$ Tris [pH 7.5], 1mM DTT, and protease inhibitors). Kinase reactions were performed in $10 \mu \mathrm{l}$ of KB, 2 pmole of $\left[\gamma_{-}{ }^{32} \mathrm{P}\right]-\mathrm{ATP}$ (Perkin Elmer/ NEN) and $2 \mu \mathrm{g}$ of recombinant GST, GST-Gcr2, GST-Gcr2(S365A), or GST-CTD substrate protein and incubated for 20 minutes at $30^{\circ} \mathrm{C}$. Reactions were resolved by $10 \%$ SDS-PAGE and visualized by exposure to Kodak Biomax film.

For analysis of phosphorylated Gcr2 peptides, ${ }^{32} \mathrm{P}$-labled wild type or S356A GST-Gcr2 protein was recovered from SDS-PAGE gels and digested with sequencing grade trypsin (Boehringer Mannheim). Peptides were resolved on cellulose thin layer plates by electrophoresis at $\mathrm{pH} 1.9$ followed by chromatography in butanol/ acetic acid/ $\mathrm{H}_{2} \mathrm{O} /$ pyridine (75:15:60:50, by volume) in the second dimension. Phosphopeptides were visualized by exposure to Biomax film (Nelson et al., 2003). Phosphoamino acid analysis of tryptic peptides from the in vitro kinase reactions was performed as described previously (Sadowski et al., 1991).

\section{Growth assays}

Overnight cultures grown in SC-TRP liquid media were diluted to $0.5 \mathrm{OD}_{600}, 10$-fold serially diluted and spotted onto SC-TRP plates with or without the indicated amounts of hydroxyurea (HU) (Sigma), methyl methanesufonate (MMS) (Sigma), formamide (Sigma), sodium chloride 
$(\mathrm{NaCl})$ (Bioshop), ethanol, or glycerol. Plates were incubated at the indicated temperatures for 3-5 days.

\section{RT-qPCR}

Overnight cultures were diluted to $0.15 \mathrm{OD}_{600}$ and grown to $0.5 \mathrm{OD}_{600}$ in SC-TRP media. RNA was extracted and purified using the Qiagen RNeasy Mini Kit. cDNA was generated using the Qiagen QuantiTect Reverse Transcription Kit and analyzed using the PerfeCTa SYBR green FastMix (VWR) and a Rotor-Gene 6000 (Qiagen). mRNA levels were quantified from three independent biological replicates using TUB1 as a control gene. Primer sequences are listed in Table 3.

\section{Data availability}

Complete gene expression and ChIP-chip datasets can be accessed from Gene Expression Omnibus (GEO) with accession numbers GSE166614 and GSE166737 respectively. 


\section{RESULTS}

\section{A conditional depletion strategy to investigate the role of Cdk8 in transcription regulation}

Slow growth phenotypes can give rise to altered gene expression profiles that are independent of the underlying genetic alteration (O'Duibhir et al., 2014). Yeast mutants bearing deletion of CDK8 display slow growth (doubling time of 2.3 hours compared to 1.5 hours in wild type cells) which may confound understanding the role of this kinase in gene regulation. To examine the immediate effects of CDK8 loss on transcription, we used the anchor-away (AA) system, which causes nuclear proteins to become conditionally sequestered in the cytoplasm by chemical induced multimerization of FKBP12 and FRP fusions in the presence of rapamycin (Haruki et al., 2008). To facilitate comparison of our results with previously generated expression profiles of strains lacking genes encoding mediator subunits or gene-specific transcription factors (Kemmeren et al., 2014; Peppel et al., 2005), we used an anchor away strain generated in the S288C/ BY4742 background (tor1-1, fpr1 RPL13A-FKBP12)(de Jonge et al., 2017). We confirmed that this strain was insensitive to rapamycin and did not have alterations in global gene expression (Supplementary Figure 1A-D). Furthermore, fusion of a tandem FKBP12-rapamycin-binding (FRB) - GFP tag to the C-terminus of Cdk8 (Cdk8-AA) did not cause growth or gene expression defects under normal growth conditions (Supplementary Figure 1E and F). However, as we expected, exposure of the Cdk8-AA strain to rapamycin caused depletion of Cdk8 from the nucleus within 12 minutes, and at later time points recapitulated the growth defects and flocculation phenotypes of the cdk8 $\Delta$ mutant (Supplementary Figure 1F-H).

\section{Nuclear depletion of Cdk8 led to altered mRNA levels of specific gene subsets}

We examined the effect of nuclear Cdk8 depletion on global mRNA levels over the course of 20 hours using DNA microarrays and observed alterations within 20 minutes of rapamycin treatment (Figure 1, lanes 1 to 23). Importantly, the global mRNA expression profile 20 hours post rapamycin-induced nuclear depletion of Cdk8 was similar to that of a cdk8 mutant, further validating our approach (Figure 1, lanes 23 and 24, $R=0.9$ ). We note that a substantial portion of gene expression alterations identified in this analysis are associated with the slow growth expression profile described previously (compare Figure 1 lane 23 to lane 25, $\mathrm{R}=0.8$ ) (O'Duibhir et al., 2014). In fact, similarity of expression phenotypes between the Cdk8AA mutant and the slow growth profile expression patterns gradually increased following 
addition of rapamycin, reaching a maximum at 20 hours, an effect consistent with the gradual reduction in growth rate observed following Cdk8 nuclear depletion (Supplementary Figure 1F).

To examine direct roles of Cdk8 on gene expression, we focused on alterations that occurred shortly after its depletion. Consistent with previous observations, we identified a cluster of genes whose expression changed upon nuclear depletion of Cdk8 and whose promoter regions were enriched for binding of Msn2 (Hypergeometric test p-value $<0.3 \times 10-4$ ), a known transcription factor substrate of Cdk8 (Chi, 2001) (Figure 1, lane 29). These genes have decreased expression in an msn2 $\Delta$ mutant (Hypergeometric test $p=4.8 \times 10-6)$, but increased expression upon Cdk8 depletion, an effect in line with a role for Cdk8 in inhibiting Msn2 function (Chi, 2001) (Figure 1). Importantly, nuclear depletion of Cdk8 also produced immediate alterations in the transcription of genes that had not been previously linked to Cdk8 function. For example, we observed a small cluster of transcripts that decreased in abundance early after depletion (20 - 90 minutes), but that returned to untreated levels at later time points (Figure 1 , lane 30 overlap with lanes 3-15 p-value < 0.5 x 10-4, hypergeometric test). A focus on these genes revealed that they were enriched for Bas 1 binding sites within their promoter regions, and accordingly had decreased mRNA levels in a bas1 $1 \Delta$ mutant. As such, our conditional depletion approach indicated that Cdk8 may be a positive regulator of this transcription factor, an effect that was missed in earlier cdk8 $\Delta$ mutant gene expression analyses.

\section{Transcription factor motif analysis highlighted a relationship between Cdk8 and Gcr1/2}

To identify additional transcription factors that may be regulated by Cdk8, we focused on genes that showed altered mRNA levels shortly after Cdk8 depletion, and performed transcription factor binding motif analysis on their promoter sequences (Figure 2A). In this analysis we observed enrichment of a motif related to binding sites for Ste12, a known Cdk8 substrate (Nelson et al., 2003) as well as Gcr1 and Gcr2 (Figure 2B), transcription factor partners for the activation of genes encoding glycolysis enzymes (Uemura and Jigami, 1992a). Although Gcr1 and Gcr2 have not previously been linked to Cdk8, work in mammalian cells reported a role for Cdk8 kinase activity in regulating the expression of genes involved in glycolysis, the mechanisms of which remain poorly understood (Galbraith et al., 2017). Analysis of the gene expression pattern of a gcr2 $\Delta$ mutant (Figure 1, gcr2 $\Delta$, lane 28 ) revealed that it too was confounded by slow growth $(R=0.7$, lane 25 versus lane 28$)$, which may explain why genes whose expression was altered by loss of $g c r 2$ show no significant enrichment for Gcr2 binding at their promoters (Harbison et al., 2004; Maclsaac et al., 2006). As such, a bona fide 
relationship between Cdk8 and Gcr2 may exist but may have been missed because of confounding effects related to slow growth caused by cdk8 deletion.

To determine if Cdk8 may have a direct role in the regulation of Bas1, Gcr1 and/or Gcr2, we examined these proteins for potential Cdk8 phosphorylation sites - serine or threonine residues flanked by a proline 1 or 2 residues toward the $C$ terminus and a proline 2 to 4 residues toward the $\mathrm{N}$ terminus (Figure 2C) (Raithatha et al., 2011). No candidate Cdk8 phosphorylation sites were detected in the Bas1 protein sequence, however Gcr1 contained two sites (S427 (PFSP) and S538 (PESP)) and Gcr2 contained one site (S365 (PTSP)) with sequence similarity to previously described Cdk8 phosphorylation sites on Ste12, Phd1, and Gcn4 (Figure 2C). Examining conservation of the residues on Gcr1 and Gcr2 revealed that the potential phosphorylation site on Gcr2 was highly conserved across fungal species (Figure 2D), while the potential sites on Gcr1 were not (Figure 2E). These observations suggest a direct regulatory relationship between Cdk8 and the transcription factors Gcr1 and Gcr2.

\section{Gcr2 promoter occupancy at glycolysis genes was affected by nuclear depletion of Cdk8}

To examine if Cdk8 and Gcr1/Gcr2 functionally interact, we focused our analysis on their target loci. In yeast, glycolysis gene activation is dependent on the transcription factors Rap1, Gcr1 and Gcr2 (Huie et al., 1992; Uemura and Fraenkel, 1990) and consistently, their promoters contain UAS ${ }_{\text {RPG }}$ and CT box DNA motifs that are recognized by Rap1 and Gcr1 respectively (Figure 3A). At these sites, Gcr2 does not bind DNA directly, but instead is recruited to glycolysis gene promoters via interaction with Gcr1 (Deminoff and Santangelo, 2001; Uemura and Jigami, 1992b). In this complex, Gcr2 may provide transcriptional activation function. Focusing our expression analysis on genes encoding glycolysis enzymes revealed that the loss of GCR2 resulted in a decrease in their mRNA levels (Figure 3B, lane 26), an effect consistent with previous reports (Uemura and Fraenkel, 1990). Supporting a role for Cdk8 in the regulation of glycolysis gene expression, nuclear depletion of Cdk8 resulted in a progressive increase in the mRNA levels of a subset of glycolysis genes, an effect that was evident 50 min after depletion but that was in part confounded by the slow growth phenotype (Figure 3B, compare lanes 6-23 to lane 25).

Finding that the effect of Cdk8 on gene expression extended to Gcr1/ Gcr2-dependent glycolysis genes prompted us to examine if Cdk8 altered the recruitment of Gcr1 and or Gcr2 to glycolysis gene promoters. To this end, we performed chromatin immunoprecipitation and analysis by RT-qPCR. Examination of the PYK1 gene, which encodes pyruvate kinase, a key 
enzyme in the glycolysis pathway, revealed that nuclear depletion of Cdk8 resulted in a significant increase in Gcr2 promoter occupancy within 60 minutes (Figure 3C). Expanding this analysis genome wide revealed that genes encoding glycolysis enzymes were enriched for Gcr2 occupancy at their promoters, and that Gcr2 occupancy levels significantly increased upon nuclear depletion of Cdk8 (Figure 3D and E). This effect did not extend to Gcr1, which showed no significant changes in occupancy at the PYK1 gene promoter or additional genes encoding glycolysis enzymes upon nuclear depletion of Cdk8 (Figure 3C and D). These observations indicate that the interaction of Gcr2 with responsive gene promoters is regulated by Cdk8.

\section{Gcr2 phosphorylation occurred in vivo and was dependent on Cdk8}

Cdk8 has well established roles in modulating gene expression via phosphorylation of several gene-specific transcription factors (Chi, 2001; Nelson et al., 2003; Raithatha et al., 2011; Rosonina et al., 2012). To determine if Gcr2 is phosphorylated in a Cdk8-dependent manner in vivo, Gcr2 was immunoprecipitated from cells with and without nuclear depletion of Cdk8 followed by treatment with or without lambda phosphatase. Treatment of Gcr2 protein recovered from cells without Cdk8 nuclear depletion with lambda phosphatase resulted in the appearance of a faster migrating species compared to untreated samples, indicating the presence of Gcr2 phosphorylation under normal growth conditions (Figure 4A). Consistent with a role for Cdk8 in modulating Gcr2 phosphorylation in vivo, we observed a reduction in the slower migrating species upon Cdk8 nuclear depletion, an effect observed within 30 minutes, and which persisted 2 hours after addition of rapamycin (Figure 4A and B). We note that depletion of Cdk8 from the cell nucleus reduced but did not completely eliminate the slower migrating phosphatase-sensitive species of Gcr2, even 2 hours after of rapamycin treatment, findings consistent with multiple residues on Gcr2 phosphorylated in vivo, some of which are likely targeted by additional kinases (Albuquerque et al., 2008)

\section{Cdk8 directly phosphorylated Gcr2 in vitro}

Evidence of a role for Cdk8 in Gcr2 phosphorylation in vivo (Figure 4A) paired with the presence of a sequence motif on Gcr2 that resembles phosphorylation sites on known Cdk8 substrates (Figure 2C), prompted us to examine if Cdk8 directly phosphorylated Gcr2. For this, we performed in vitro kinase reactions using recombinant Gcr2 and Gcr2-S365A mutant proteins (Figure 5A) as substrates for wild type or kinase deficient Cdk8 (D290A) recovered from yeast using a FLAG-epitope tag. In these reactions we found that wild type Cdk8 robustly phosphorylated Gcr2 but less efficiently the Gcr2-S365A mutant (Figure 5B). Importantly, we did 
not observe phosphorylation of any substrates in reactions with the Cdk8 kinase deficient mutant (D290A).

To determine if Cdk8 specifically targeted S365 of Gcr2, we performed phosphopeptide analysis of Gcr2 and Gcr2-S365A mutant proteins phosphorylated by Cdk8 in vitro. We found that Cdk8 kinase-dependent phosphorylation of wild type Gcr2 predominately occurred on a single tryptic peptide (Figure 5C, labelled $1 \mathrm{a}$ and $1 \mathrm{~b}$ ) that was not present in reactions with the Gcr2-S365A mutant. Consistently, phosphoamino acid analysis of this phosphopeptide (1a and b) only produced phosphoserine (not shown), effects consistent with S365 being the target site. Nevertheless, we note that phosphorylation of wild type and Gcr2-S365A in vitro produced 2 additional phosphopeptides (Figure 5C, labeled 2 and 3), indicating that Cdk8 may phosphorylate additional sites on Gcr2, but with lower efficiency.

\section{Phosphorylation of Gcr2 at $\mathbf{S 3 6 5}$ was required for growth on glucose and expression of glycolysis genes}

Having established a direct kinase-substrate relationship between Gcr2 and Cdk8 in vitro, we examined if Cdk8-dependent phosphorylation of Gcr2 had any significance in vivo. To test this, we generated plasmid-based phospho-mutant (gcr2-S365A) and phospho-mimic (gcr2$S 365 D$ ) alleles of GCR2 and introduced them into a gcr2 $\Delta$ mutant background. Strikingly, across several growth conditions the phospho-mutant (S365A) of GCR2 recapitulated the gcr2 $\triangle$ mutant growth phenotype, an effect not seen with the phospho-mimic allele of GCR2 (S365D, Figure 6A) and indicative of phosphorylation at $\$ 365$ being critical for Gcr2 function. To determine if Gcr2 phosphorylation was important for the expression of glycolysis genes, we examined the ability of phospho-mutant and phospho-mimic alleles to sustain expression of representative gene encoding glycolysis enzymes. In line with the growth phenotypes described above, the phospho-mutant allele of GCR2 recapitulated the gcr2 $\triangle$ mutant gene expression defects, showing decreased mRNA levels for several genes in the glycolysis pathway, effects that were significant for PYK1 and PGI1, with TPI1 and PGK1 showing a consistent trend (Figure 6B and C). Again, this effect was not observed with the phospho-mimic version of GCR2, indicating that phosphorylation of Gcr2 at S365, a site targeted by Cdk8, was critical for Gcr2's role as a transcriptional activator of genes encoding enzymes in the glycolysis pathway. 


\section{DISCUSSION}

The work presented here describes a direct role for Cdk8 in the regulation of genes encoding glycolysis enzymes through phosphorylation of Gcr2, a key transcriptional activator. Using high-resolution gene expression time course profiling following Cdk8 nuclear depletion, we found a connection to transcription factors that were previously not linked to Cdk8: Bas1, Gcr1 and Gcr2. Analysis of the amino acid sequences of these transcription factors identified motifs that mirrored known Cdk8 target sites on both Gcr1 and Gcr2, highlighting their potential as direct Cdk8 substrates. In vivo analysis supported the existence of Gcr2 phosphorylation under normal growth conditions and revealed that this modification was dependent on Cdk8 residing in the cell nucleus. A direct kinase substrate relationship between Cdk8 and Gcr2 was supported by in vitro kinase reactions, which identified amino acid S365 as a key site on Gcr2 targeted by Cdk8 for phosphorylation. Abolishing phosphorylation of Gcr2 at S365 via phosphomutant alleles revealed that this modification was necessary for normal Gcr2 function, including the activation of genes encoding glycolysis enzymes.

Altogether, our findings uncovered a nuanced mechanism by which Cdk8 modulates Gcr2 and thus the expression of genes encoding glycolysis enzymes. One the one hand, we found that Cdk8 normally functioned to decrease glycolysis gene mRNA levels by limiting Gcr2, and to a lesser extent Gcr1, occupancy at target gene promoters, an effect that persisted 2 hours post nuclear depletion of Cdk8. On the other hand, we found that Cdk8 functioned to activate glycolysis gene expression by targeting Gcr2 S365 for phosphorylation. This discrepancy may reflect the effect of transient vs. stable perturbations on gene expression regulation given that a role of Cdk8 in inhibiting glycolysis gene expression was observed following transient depletion of Cdk8 from the cell nucleus, whereas a role for Cdk8 in stimulating glycolysis gene expression was observed upon stable loss of the main Cdk8 target site on Gcr2, effects that were indistinguishable from the gcr2 null mutant. Consistently, a role for Cdk8 in activating glycolysis gene expression was reported previously in colon cancer cell lines using constitutive Cdk8 hypomorphic alleles (Galbraith et al., 2017). A dual function for Cdk8 in glycolysis gene regulation is in line with its role in context-specific transcription regulation and may be rooted in its ability to phosphorylate additional sites on Gcr2 as well as other transcription factors, perhaps Gcr1. 
In addition to uncovering a new functional relationship between Cdk8 and Gcr2, this work also highlights the utility of conditional depletion strategies paired with dynamic measures of gene expression to uncover mechanisms of transcription regulation that may be missed by traditional approaches using constitutive null mutants. Overall, our work indicates that conditional depletion strategies may be particularly well-suited to separate confounding effects emerging from null mutants, including those associated with slow growth phenotypes which have the potential to mask true associations (O'Duibhir et al., 2014). In this case, depleting Cdk8 from the nucleus using the anchor away system allowed us to focus on the earliest gene expression alterations, which emerged before significant slow growth-associated defects could be detected. Examining rapid gene expression alterations following nuclear depletion of Cdk8, supported a role for $\mathrm{Cdk} 8$ in gene-specific transcription regulation. More specifically, within 1020 minutes post nuclear depletion of Cdk8 we detected increased expression of genes regulated by Msn2, effects consistent with Cdk8 negatively regulating this transcription factor via nuclear exclusion (Chi, 2001). Additionally, we detected a set of Bas1-regulated genes whose expression levels were reduced within 20 minutes of Cdk8 nuclear depletion. Given that these genes show high levels of Bas1 occupancy at their promoters and their expression is inhibited by deletion of BAS1 suggests that Cdk8 may function to stimulate Bas1 activity. Examination of later times points following Cdk8 depletion revealed increasing similarity to the slower growth gene expression profile, which can largely be attributed to downregulation of Gcr2 and upregulation of Msn2 function. Thus, our work suggests that a key role of the Cdk8 kinase is to regulate gene-specific transcriptional regulatory proteins, rather than general components of the transcriptional machinery, for example by phosphorylation of the RNA Polymerase II CTD (Hallberg et al., 2004; Liao et al., 1995; Liu et al., 2004, 2000; Miller et al., 2012; Peppel et al., 2005).

Consistent with the results presented here, previous work in yeast has highlighted both positive and negative roles for Cdk8 on gene-specific transcription regulation via phosphorylation of sequence-specific transcription factors. As a negative regulator of transcription, Cdk8 phosphorylates Ste12, Phd1 and Gcn4, targeting them for degradation and leading to the repression of their respective target loci (Nelson et al., 2003; Raithatha et al., 2011; Rosonina et al., 2012). As a positive regulator, Cdk8 phosphorylates Gal4, a modification required for full induction of the $G A L$ genes although the exact mechanism remains incompletely understood. Our analysis of cells carrying phospho-mutant alleles of Gcr2 suggests that Cdk8dependent phosphorylation is necessary for Gcr2's role as a transcriptional activator, an effect 
similar to the effect of Cdk8 on Gal4. However, as described above a role for Cdk8 on Gcr2 function is nuanced, also involving transient inhibition of Gcr2 occupancy at target gene promoters.

It is well established that the transcriptional regulation of genes encoding glycolysis enzymes requires the combined activity of several transcription factors: Rap1, Gcr1 and Gcr2. At these genes, Gcr2 associates with target promoter regions via direct interaction with Gcr1, which recognizes a CT box motif on the promoter of genes encoding glycolysis enzymes (Huie et al., 1992; Uemura and Fraenkel, 1990). Exactly how Rap1, Gcr1, and Gcr2 function to activate transcription is at present not well understood. Nevertheless, it is clear that transcription of genes encoding glycolysis enzymes requires the recruitment of Gcr1 to CT box motifs and the binding of Gcr2 to Gcr1. Our work indicates that regulation of glycolysis genes also involves decreasing transcription via inhibiting Gcr2 promoter occupancy as well as activation of gene expression via Gcr2 phosphorylation at $\mathrm{S} 365$ by Cdk8. In the future, it would be of interest to investigate the role of Cdk8 on Gcr1 function and to determine if Gcr2 phosphorylation modulates its ability to interact with Gcr1.

The work described here builds on previous findings in human colon cancer cells lines which showed that Cdk8 kinase activity is required for the activation of glycolysis genes. Although it remains to be determined if the mechanism linking Cdk8 to glycolysis we describe in yeast is conserved in humans, evidence presented here suggests that Cdk8 may function in the regulation of glycolysis across species. As such, our work further emphasizes a key role for Cdk8 in the modulation of metabolism through effects on several pathways including the regulation of genes important for growth on galactose media via phosphorylation of Gal4 and low nitrogen conditions via phosphorylation of Gnc4, Ste12 and Phd1. How these activities are coordinated and whether there is any cross-talk between these pathways remains an open question.

\section{FUNDING}

This work was supported by the Netherlands Organisation for Scientific Research (NWO) grants 86411010, 016108607, 81702015, 05071057, 91106009; the European Research Council (ERC) grant 671174 DynaMech."; and the Natural Sciences and Engineering Research Council of Canada (RGPIN-2016-04297 and RGPIN-F19-05392). M.J.A acknowledges support from a postdoctoral fellowship from the Natural Sciences and Engineering Research Council of Canada 


\section{ACKNOWLEDGEMENTS}

We thank members of the Holstege, Kobor and Sadowski group for support, discussions and technical assistance.

\section{FIGURE LEGENDS}

Figure 1: Gene expression alterations upon nuclear depletion of Cdk8. Heat map of gene expression changes and GSTF binding profiles. Genes were cosine clustered based on lanes 124 (fold change $>1.7$ and $p<0.05$ ). Lanes 1-23: Time course of gene expression changes following addition of rapamycin to the Cdk8-AA strain. Lane 24: CDK8 deletion (cdk8D) profile. Lane 25: Changes associated with slow growth (O'Duibhir et al., 2014). Lanes 26-28: gene expression changes associated with the indicated gene-specific transcription factor deletion strains (Kemmeren et al., 2014). Lanes 29-31: gene-specific transcription factor occupancy (Maclsaac et al., 2006).

Figure 2: Gcr2 contained a conserved Cdk8 phosphorylation motif. (A) Transcripts whose mRNA level increase shortly after Cdk8 depletion were clustered to an arbitrarily drawn gene expression profile. (B) DNA motif enriched of the gene promoters identified in (A) corresponds to a combined Gcr1/2 and Ste12 motif (from (Gupta et al., 2007)) (C) Potential serine phosphorylation sites $\left(^{*}\right)$ on Gcr1 and Gcr2 compared to confirmed sites on Ste12 (Nelson et al., 2003), Phd1 (Raithatha et al., 2011) and Gcn4 (Chi, 2001). (D and E) Multiple sequence alignment displaying homologous Gcr1 and Gcr2 proteins with the highest protein sequence similarity across the indicated fungal species. We found that the serine $\left(^{*}\right)$ in Gcr2 that may be targeted for phosphorylation by Cdk8 is highly conserved across species

Figure 3: Promoter binding of Gcr2 was dependent on Cdk8 in vivo. (A) Schematic of a typical Gcr2-depend gene promoter, highlighting the Rap1 and Gcr1 binding sites. (B) Heat map of gene expression changes upon nuclear depletion of Cdk8 at genes encoding glycolysis enzymes (lanes 1-23). The cdk8 (lane 24), grc2 4 (lane 26) and slow growth (lane 25) gene expression profiles are included for comparison. (C) ChIP-qPCR of Gcr2-V5 (left) and Gcr1-V5 (right) on the PYK1 promoter before and 60 minutes after Cdk8 nuclear depletion ( $p$ values calculated by Student's t-test). (D) ChIP-chip of Gcr2-V5 (left) and Gcr1-V5 (right) revealed enrichment at genes encoding glycolysis enzymes. Nuclear depletion of Cdk8 for $60 \mathrm{~min}$ resulted in a significant increase in Gcr2 occupancy at glycolysis gene promoter, an effect not 
seen for Gcr1 or at other loci ( $p$ values calculated by two-sided Wilcoxon tests). (E) Representative ChIP-chip genomic binding profiles for Gcr2 before and 60 minutes after Cdk8 nuclear depletion.

Figure 4: Cdk8 modulated Gcr2 phosphorylation in vivo (A) SDS-PAGE followed by V5 immuno-blot showing lambda phosphatase treatment of $\mathrm{V} 5$ immunoprecipitated Gcr2 protein before and 60 min after Cdk8 nuclear depletion. (B) SDS-PAGE followed by V5 immuno-blot of whole cell lysate from a Cdk8-AA/Gcr2-V5 strain during a rapamycin induced Cdk8 nuclear depletion time course.

Figure 5: Cdk8 phosphorylated Gcr2 S365 in vitro. (A) Gcr2, Gcr2-S365A, GST-CTD and GST were purified from $E$. coli and used for in vitro kinase reactions. (B) Flag-tagged wild type (right) or kinase deficient (D290A) (left) Cdk8 was immunoprecipitated from a $\Sigma 1278 \mathrm{~b}$ background and was used for in vitro kinase reactions. Gcr2 but not Gcr2-S365A was robustly phosphorylated by wild type but not kinase deficient Cdk8. GST-CTD and GST proteins were used as positive and negative controls respectively. Reactions were analyzed by SDS-PAGE and autoradiography. (C) Phosphopeptide analysis of Gcr2 and Gcr2-S365A proteins phosphorylated by wild type Cdk8. Trypsin digestion of Gcr2 produced four phosphorylated peptides (labelled 1a, 1b, 2, and 3), two of which (1a and 1b) were absent in the Gcr2-S365A mutant.

Figure 6: Gcr2-S365 phosphorylation was required for growth and transcription factor function. (A) Loss of Gcr2-S365 phosphorylation recapitulated the gcr2 $\triangle$ mutant growth phenotypes. Cells with the indicated mutations were 10 -fold serially diluted, spotted on SC-TRP media and grown for 3-5 days with the indicated carbon source or drug concentrations. (B) RTqPCR analysis of mRNA levels for representative genes encoding glycolysis enzymes (PG/1, TPI1, PGK1 and PYK1) normalized to TUB1 mRNA levels (Lu and Kobor, 2014). Error bars represent standard deviation from three independent biological replicates. The gcr2-S365A mutant mirrored the gcr2 $\triangle$ mutant gene expression defects at the PYK1 and PGK1 genes, underscoring the importance of Gcr2 phosphorylation in gene expression. (C) Schematic of the glycolysis pathway, highlighting the genes tested by RT-qPCR.

Supplementary Figure 1: Construction and validation of a conditional Cdk8-AA strain in the BY4742 background. (A) Growth of the Parental-AA strain. (B-E) Scatterplots of gene 
expression changes of $(B)$ wildtype cells with and without rapamycin treatment; $(C)$ Parental-AA compared to wildtype; (D) Parental-AA treated with and without rapamycin treatment; and (E) Cdk8 tagged with FRB-GFP (Cdk8-AA) compared to Parental-AA. The numbers on the axis refer to the averaged log2 fluorescent dye intensities of the microarray probes representing each gene (dots). (F) Growth of Cdk8-AA strain before and after rapamycin addition. Addition of rapamycin is indicated by the arrow labelled "Rapa". Cultures were diluted into fresh media with rapamycin twice to avoid nutrient depletion. (G) Fluorescence microscopy of Cdk8-AA (Cdk8FRB-GFP) before and after rapamycin addition, scale bar $10 \mu \mathrm{M}$. $(\mathrm{H})$ Exposure of the Cdk8-AA mutant to Rapamycin recapitulates the flocculent phenotype of the cdk8 $\Delta$ mutant.

\section{TABLES}

Table 1. Strains used in this study

\begin{tabular}{|c|c|c|c|}
\hline Strain & Genotype & Background & Source \\
\hline MA-Y9 & $\begin{array}{l}\text { Matalpha GCR2::KAN ade2-1 can1-100 his3-11 leu2-3,112 trp1-1 ura3- } \\
1 \text { LYS2 pRS314[] }\end{array}$ & W303 & This study \\
\hline MA-Y10 & $\begin{array}{l}\text { Matalpha GCR2::KAN ade2-1 can1-100 his3-11 leu2-3,112 trp1-1 ura3- } \\
1 \text { LYS2 pRS314[GCR2] }\end{array}$ & W303 & This study \\
\hline MA-Y11 & $\begin{array}{l}\text { Matalpha GCR2::KAN ade2-1 can1-100 his3-11 leu2-3,112 trp1-1 ura3- } \\
1 \text { LYS2 pRS314[gcr2-S365A] }\end{array}$ & W303 & This study \\
\hline MA-Y12 & $\begin{array}{l}\text { Matalpha GCR2::KAN ade2-1 can1-100 his3-11 leu2-3,112 trp1-1 ura3- } \\
1 \text { LYS2 pRS314[gcr2-S365D] }\end{array}$ & W303 & This study \\
\hline $\begin{array}{l}\text { BY- } \\
\text { Parenta } \\
\text { I-AA }\end{array}$ & $\begin{array}{l}\text { tor1-1; Dfpr1; RPL13A-2xFKBP12-NATMX6; MET15; his3-1; leu2; lys2; } \\
\text { ura3; MATalpha }\end{array}$ & BY4742 & $\begin{array}{l}\text { (de Jonge } \\
\text { et al., } \\
2017 \text { ) }\end{array}$ \\
\hline $\begin{array}{l}\text { BY- } \\
\text { cdk8AA }\end{array}$ & $\begin{array}{l}\text { tor1-1; Dfpr1; RPL13A-2xFKBP12-NATMX6; MET15; his3-1; leu2; lys2; } \\
\text { ura3; cdk8-FRB-yEGFP-hnhMX6 MATalpha }\end{array}$ & BY4742 & This study \\
\hline $\begin{array}{l}\text { BY- } \\
\text { cdk8AA } \\
\text { GCR1- } \\
\text { 3V5-his }\end{array}$ & $\begin{array}{l}\text { tor1-1; Dfpr1; RPL13A-2xFKBP12-NATMX6; MET15; his3-1; leu2; lys2; } \\
\text { ura3; gcr1-3V5-HIS; cdk8-FRB-yEGFP-hnhMX6 MATalpha }\end{array}$ & BY4742 & This study \\
\hline $\begin{array}{l}\text { BY- } \\
\text { cdk8AA } \\
\text { GCR2- } \\
\text { 3V5-his }\end{array}$ & $\begin{array}{l}\text { tor1-1; Dfpr1; RPL13A-2xFKBP12-NATMX6; MET15; his3-1; leu2; lys2; } \\
\text { ura3; gcr2-3V5-HIS; cdk8-FRB-yEGFP-hnhMX6 MATalpha }\end{array}$ & BY4742 & This study \\
\hline
\end{tabular}

Table 2. Plasmids used in this study

\begin{tabular}{|l|l|l|}
\hline Plasmid & \multicolumn{1}{|c|}{ Relevant Genotype } & \multicolumn{1}{c|}{$\begin{array}{c}\text { Source or } \\
\text { Reference }\end{array}$} \\
\hline pMA6 & pRS314 & This study \\
\hline pMA81 & pRS314[GCR2] & This study \\
\hline
\end{tabular}




\begin{tabular}{|c|c|c|}
\hline pMA82 & pRS314[gcr2-S365A] & This study \\
\hline pMA83 & pRS314[gcr2-S365D] & This study \\
\hline plS484 & URA3 ARS-CEN TEF1p- $\Sigma 1278 \mathrm{~b}$ CDK8-3XFLAG-His 6 & (Nelson et al., 2003) \\
\hline pIS529 & $\begin{array}{l}\text { URA3 ARS-CEN TEF1p- } \Sigma 1278 \mathrm{~b} \text { CDK8D290A-3XFLAG- } \\
\text { His } 6_{6}\end{array}$ & (Nelson et al., 2003) \\
\hline
\end{tabular}

Table 3. Primers used in this study

\begin{tabular}{|l|l|l|l|l|}
\hline $\begin{array}{c}\text { Primer } \\
\text { name }\end{array}$ & \multicolumn{1}{|c|}{ Forward Sequence } & \multicolumn{1}{|c|}{ Reverse Sequence } & Use & $\begin{array}{l}\text { Source or } \\
\text { Reference }\end{array}$ \\
\hline PGK1 & CAAGAGCTCTGCTGCTGGTA & AAAGCAACACCTGGCAATTC & RT & $\begin{array}{l}\text { (Aristizabal } \\
\text { et al., 2019) }\end{array}$ \\
\hline PYK1 & TCAACGCCGTTACCACTATG & TGGAGGTTGGCTTTGGAGTA & RT & This study \\
\hline TPI1 & TTGTCGCTTACGAACCAGTC & AGCGGAACCACCGTATAAGA & RT & This study \\
\hline PGI1 & $\begin{array}{l}\text { TGGTTCACCAAGGTACCAAG } \\
\text { T }\end{array}$ & TGGCACCTTCAGCCTTAACT & RT & This study \\
\hline TUB1 & TCTTGGTGGTGGTACTGGTT & $\begin{array}{l}\text { TGGATTTCTTACCGTATTCAG } \\
\text { CG }\end{array}$ & RT & $\begin{array}{l}\text { (Lu and } \\
\text { Kobor, 2014) }\end{array}$ \\
\hline PYK1 & TCGTCGGTTGTGATACGGTC & CGGAAAACTTTCGGGTAGCG & ChIP & This study \\
\hline POL1 & $\begin{array}{l}\text { TTCAGAGGTGGATCAGGGTG } \\
\text { T }\end{array}$ & $\begin{array}{l}\text { GCTTATGGGGATCAGTTTCA } \\
\text { GTTTT }\end{array}$ & ChIP & $\begin{array}{l}\text { (de Jonge et } \\
\text { al., 2017) }\end{array}$ \\
\hline $\begin{array}{l}\text { HMR- } \\
\text { RT }\end{array}$ & $\begin{array}{l}\text { ACGATCCCCGTCCAAGTTAT } \\
\text { G }\end{array}$ & $\begin{array}{l}\text { CTTCAAAAGGAGTCTTAATTT } \\
\text { CCCTG }\end{array}$ & ChIP & $\begin{array}{l}\text { (de Jonge et } \\
\text { al., 2017) }\end{array}$ \\
\hline
\end{tabular}

\section{REFERENCES}

Albuquerque CP, Smolka MB, Payne SH, Bafna V, Eng J, Zhou H. 2008. A Multidimensional Chromatography Technology for In-depth Phosphoproteome Analysis. Molecular \& Cellular Proteomics 7:1389-1396. doi:10.1074/mcp.m700468-mcp200

Altschul S. 1997. Gapped BLAST and PSI-BLAST: a new generation of protein database search programs. Nucleic Acids Research 25:3389-3402. doi:10.1093/nar/25.17.3389

Aristizabal MJ, Dever K, Negri GL, Shen M, Hawe N, Benschop JJ, Holstege FCP, Krogan NJ, Sadowski I, Kobor MS. 2019. Regulation of Skn7-dependent, oxidative stress-induced genes by the RNA polymerase II-CTD phosphatase, Fcp1, and Mediator kinase subunit, Cdk8, in yeast. J Biol Chem 294:16080-16094. doi:10.1074/jbc.RA119.008515

Aristizabal MJ, Negri GL, Benschop JJ, Holstege FCP, Krogan NJ, Kobor MS. 2013. Highthroughput genetic and gene expression analysis of the RNAPII-CTD reveals unexpected connections to SRB10/CDK8. PLoS Genet 9:e1003758. doi:10.1371/journal.pgen.1003758

Bailey TL, Elkan C. 1994. Fitting a mixture model by expectation maximization to discover motifs in biopolymers. Proc Int Conf Intell Syst Mol Biol 2:28-36.

Bakel H van, Holstege FCP. 2004. In control: systematic assessment of microarray performance. EMBO reports 5:964-969. doi:10.1038/sj.embor.7400253

Bakel $\mathrm{H}$ van, Werven FJ van, Radonjic M, Brok MO, Leenen D van, Holstege FCP, Timmers HTM. 2008. Improved genome-wide localization by ChIP-chip using double-round T7 RNA polymerase-based amplification. Nucleic Acids Research 36:e21-e21. doi:10.1093/nar/gkm1144

Balciunas D, Ronne H. 1995. Three subunits of the RNA polymerase II mediator complex are involved in glucose repression. Nucleic Acids Research 23:4421-4425.

doi:10.1093/nar/23.21.4421 
Carlson M, Osmond BC, Neigeborn L, Botstein D. 1984. A SUPPRESSOR OF snf1 MUTATIONS CAUSES CONSTITUTIVE HIGH-LEVEL INVERTASE SYNTHESIS IN YEAST. Genetics 107:19-32. doi:10.1093/genetics/107.1.19

Chi Y. 2001. Negative regulation of Gcn4 and Msn2 transcription factors by Srb10 cyclindependent kinase. Genes \& Development 15:1078-1092. doi:10.1101/gad.867501

Conaway RC, Conaway JW. 2011. Function and regulation of the Mediator complex. Current Opinion in Genetics \& Development 21:225-230. doi:10.1016/j.gde.2011.01.013

Cullen PJ, Sprague GF. 2012. The Regulation of Filamentous Growth in Yeast. Genetics 190:23-49. doi:10.1534/genetics.111.127456

de Jonge WJ, O'Duibhir E, Lijnzaad P, van Leenen D, Groot Koerkamp MJ, Kemmeren P, Holstege FC. 2017. Molecular mechanisms that distinguish TFIID housekeeping from regulatable SAGA promoters. The EMBO Journal 36:274-290.

doi:10.15252/embj.201695621

Deminoff SJ, Santangelo GM. 2001. Rap1p requires Gcr1p and Gcr2p homodimers to activate ribosomal protein and glycolytic genes, respectively. Genetics 158:133-143.

Galbraith MD, Andrysik Z, Pandey A, Hoh M, Bonner EA, Hill AA, Sullivan KD, Espinosa JM. 2017. CDK8 Kinase Activity Promotes Glycolysis. Cell Rep 21:1495-1506. doi:10.1016/j.celrep.2017.10.058

Gupta S, Stamatoyannopoulos JA, Bailey TL, Noble W. 2007. Quantifying similarity between motifs. Genome Biology 8:R24. doi:10.1186/gb-2007-8-2-r24

Hallberg M, Polozkov GV, Hu G-Z, Beve J, Gustafsson CM, Ronne H, Bjorklund S. 2004. Sitespecific Srb10-dependent phosphorylation of the yeast Mediator subunit Med2 regulates gene expression from the 2- $\mathrm{m}$ plasmid. Proceedings of the National Academy of Sciences 101:3370-3375. doi:10.1073/pnas.0400221101

Harbison CT, Gordon DB, Lee TI, Rinaldi NJ, Macisaac KD, Danford TW, Hannett NM, Tagne JB, Reynolds DB, Yoo J, Jennings EG, Zeitlinger J, Pokholok DK, Kellis M, Rolfe PA, Takusagawa KT, Lander ES, Gifford DK, Fraenkel E, Young RA. 2004. Transcriptional regulatory code of a eukaryotic genome. Nature 431:99-104. doi:10.1038/nature02800

Haruki H, Nishikawa J, Laemmli UK. 2008. The Anchor-Away Technique: Rapid, Conditional Establishment of Yeast Mutant Phenotypes. Molecular Cell 31:925-932. doi:10.1016/j.molcel.2008.07.020

Hengartner CJ, Thompson CM, Zhang J, Chao DM, Liao SM, Koleske AJ, Okamura S, Young RA. 1995. Association of an activator with an RNA polymerase II holoenzyme. Genes \& Development 9:897-910. doi:10.1101/gad.9.8.897

Hirst M, Kobor MS, Kuriakose N, Greenblatt J, Sadowski I. 1999. GAL4 Is Regulated by the RNA Polymerase II Holoenzyme-Associated Cyclin-Dependent Protein Kinase SRB10/CDK8. Molecular Cell 3:673-678. doi:10.1016/s1097-2765(00)80360-3

Holstege FCP, Jennings EG, Wyrick JJ, Lee TI, Hengartner CJ, Green MR, Golub TR, Lander ES, Young RA. 1998. Dissecting the Regulatory Circuitry of a Eukaryotic Genome. Cell 95:717-728. doi:10.1016/s0092-8674(00)81641-4

Huie MA, Scott EW, Drazinic CM, Lopez MC, Hornstra IK, Yang TP, Baker HV. 1992. Characterization of the DNA-binding activity of GCR1: in vivo evidence for two GCR1binding sites in the upstream activating sequence of TPI of Saccharomyces cerevisiae. Mol Cell Biol 12:2690-2700.

Katoh K, Standley DM. 2013. MAFFT Multiple Sequence Alignment Software Version 7: Improvements in Performance and Usability. Molecular Biology and Evolution 30:772780. doi: $10.1093 / \mathrm{molbev} / \mathrm{mst} 010$

Kemmeren P, Sameith K, Pasch LAL van de, Benschop JJ, Lenstra TL, Margaritis T, O'Duibhir E, Apweiler E, Wageningen S van, Ko CW, Heesch S van, Kashani MM, AmpatziadisMichailidis G, Brok MO, Brabers NACH, Miles AJ, Bouwmeester D, Hooff SR van, Bakel $H$ van, Sluiters E, Bakker LV, Snel B, Lijnzaad P, Leenen D van, Koerkamp MJAG, 
Holstege FCP. 2014. Large-Scale Genetic Perturbations Reveal Regulatory Networks and an Abundance of Gene-Specific Repressors. Cell 157:740-752.

doi:10.1016/j.cell.2014.02.054

Kim Y-J, Björklund S, Li Y, Sayre MH, Kornberg RD. 1994. A multiprotein mediator of transcriptional activation and its interaction with the C-terminal repeat domain of RNA polymerase II. Cell 77:599-608. doi:10.1016/0092-8674(94)90221-6

Kornberg RD. 2005. Mediator and the mechanism of transcriptional activation. Trends in Biochemical Sciences 30:235-239. doi:10.1016/j.tibs.2005.03.011

Lenssen E, Azzouz N, Michel A, Landrieux E, Collart MA. 2007. The Ccr4-Not Complex Regulates Skn7 through Srb10 Kinase. Eukaryotic Cell 6:2251-2259. doi:10.1128/ec.00327-06

Li L, Quinton T, Miles S, Breeden LL. 2005. Genetic Interactions Between Mediator and the Late G1-Specific Transcription Factor Swi6 inSaccharomyces cerevisiae. Genetics 171:477488. doi:10.1534/genetics.105.043893

Liao S-M, Zhang J, Jeffery DA, Koleske AJ, Thompson CM, Chao DM, Viljoen M, Vuuren HJJ van, Young RA. 1995. A kinase-cyclin pair in the RNA polymerase II holoenzyme. Nature 374:193-196. doi:10.1038/374193a0

Liu Y, Kung C, Fishburn J, Ansari AZ, Shokat KM, Hahn S. 2004. Two Cyclin-Dependent Kinases Promote RNA Polymerase II Transcription and Formation of the Scaffold Complex. Molecular and Cellular Biology 24:1721-1735. doi:10.1128/mcb.24.4.17211735.2004

Liu Y, Ranish JA, Aebersold R, Hahn S. 2000. Yeast Nuclear Extract Contains Two Major Forms of RNA Polymerase II Mediator Complexes. Journal of Biological Chemistry 276:7169-7175. doi:10.1074/jbc.m009586200

Lu PYT, Kobor MS. 2014. Maintenance of heterochromatin boundary and nucleosome composition at promoters by the Asf1 histone chaperone and SWR1-C chromatin remodeler in Saccharomyces cerevisiae. Genetics 197:133-145. doi:10.1534/genetics.114.162909

Maclsaac KD, Wang T, Gordon DB, Gifford DK, Stormo GD, Fraenkel E. 2006. An improved map of conserved regulatory sites for Saccharomyces cerevisiae. BMC Bioinformatics 7:113. doi:10.1186/1471-2105-7-113

Margaritis T, Lijnzaad P, Leenen D van, Bouwmeester D, Kemmeren P, Hooff SR van, Holstege FC. 2009. Adaptable gene-specific dye bias correction for two-channel DNA microarrays. Molecular Systems Biology 5:266. doi:10.1038/msb.2009.21

Miller C, Matic I, Maier KC, Schwalb B, Roether S, Strässer K, Tresch A, Mann M, Cramer P. 2012. Mediator Phosphorylation Prevents Stress Response Transcription During Nonstress Conditions. Journal of Biological Chemistry 287:44017-44026. doi:10.1074/jbc.m112.430140

Nelson C, Goto S, Lund K, Hung W, Sadowski I. 2003. Srb10/Cdk8 regulates yeast filamentous growth by phosphorylating the transcription factor Ste12. Nature 421:187-190. doi:10.1038/nature01243

O’Duibhir E, Lijnzaad P, Benschop JJ, Lenstra TL, van Leenen D, Groot Koerkamp MJ, Margaritis T, Brok MO, Kemmeren P, Holstege FC. 2014. Cell cycle population effects in perturbation studies. Mol Syst Biol 10:732. doi:10.15252/msb.20145172

Peppel J van de, Kettelarij N, Bakel H van, Kockelkorn TTJP, Leenen D van, Holstege FCP. 2005. Mediator Expression Profiling Epistasis Reveals a Signal Transduction Pathway with Antagonistic Submodules and Highly Specific Downstream Targets. Molecular Cell 19:511-522. doi:10.1016/j.molcel.2005.06.033

Poss ZC, Ebmeier CC, Odell AT, Tangpeerachaikul A, Lee T, Pelish HE, Shair MD, Dowell RD, Old WM, Taatjes DJ. 2016. Identification of Mediator kinase substrates in human cells 
using cortistatin A and quantitative phosphoproteomics. Cell Rep 15:436-450.

doi:10.1016/j.celrep.2016.03.030

Raithatha S, Su T-C, Lourenco P, Goto S, Sadowski I. 2011. Cdk8 Regulates Stability of the Transcription Factor Phd1 To Control Pseudohyphal Differentiation of Saccharomyces cerevisiae. Molecular and Cellular Biology 32:664-674. doi:10.1128/mcb.05420-11

Rando OJ. 2010. Genome-Wide Mapping of Nucleosomes in YeastMethods in Enzymology. Elsevier. pp. 105-118. doi:10.1016/s0076-6879(10)70005-7

Rosonina E, Duncan SM, Manley JL. 2012. Sumoylation of transcription factor Gcn4 facilitates its Srb10-mediated clearance from promoters in yeast. Genes \& Development 26:350355. doi:10.1101/gad.184689.111

Sadowski I, Niedbala D, Wood K, Ptashne M. 1991. GAL4 is phosphorylated as a consequence of transcriptional activation. Proc Natl Acad Sci U S A 88:10510-10514. doi:10.1073/pnas.88.23.10510

Smyth GK. 2005. Limma: linear models for microarray data. In Bioinformatics and computational biology solutions using $\mathrm{R}$ and Bioconductor. Edited by Gentleman R, Carey V, Dudoit S, Irizarry R, Huber W 420.

Surosky RT, Strich R, Esposito RE. 1994. The yeast UME5 gene regulates the stability of meiotic mRNAs in response to glucose. Molecular and Cellular Biology 14:3446-3458. doi:10.1128/mcb.14.5.3446

Tabtiang RK, Herskowitz I. 1998. Nuclear Proteins Nut1p and Nut2p Cooperate To Negatively Regulate a Swi4p-Dependent lacZ Reporter Gene inSaccharomyces cerevisiae. Molecular and Cellular Biology 18:4707-4718. doi:10.1128/mcb.18.8.4707

Uemura H, Fraenkel DG. 1990. gcr2, a new mutation affecting glycolytic gene expression in Saccharomyces cerevisiae. Mol Cell Biol 10:6389-6396.

Uemura H, Jigami Y. 1992a. Role of GCR2 in transcriptional activation of yeast glycolytic genes. Molecular and Cellular Biology 12:3834-3842. doi:10.1128/mcb.12.9.3834

Uemura H, Jigami Y. 1992b. Role of GCR2 in transcriptional activation of yeast glycolytic genes. Molecular and Cellular Biology 12:3834-3842. doi:10.1128/MCB.12.9.3834 
bFikgure preprint doi: https://doi.org/10.1101/2021.03.12.435012; this version posted March 12, 2021. The copyright holder for this preprint (which was not certified by peer review) is the author/funder, who has granted bioRxiv a license to display the preprint in perpetuity. It is made Granable under aCC-BY-NC-ND 4.0 International licenseBindin

Cdk8-AA depletion timecourse (minutes)

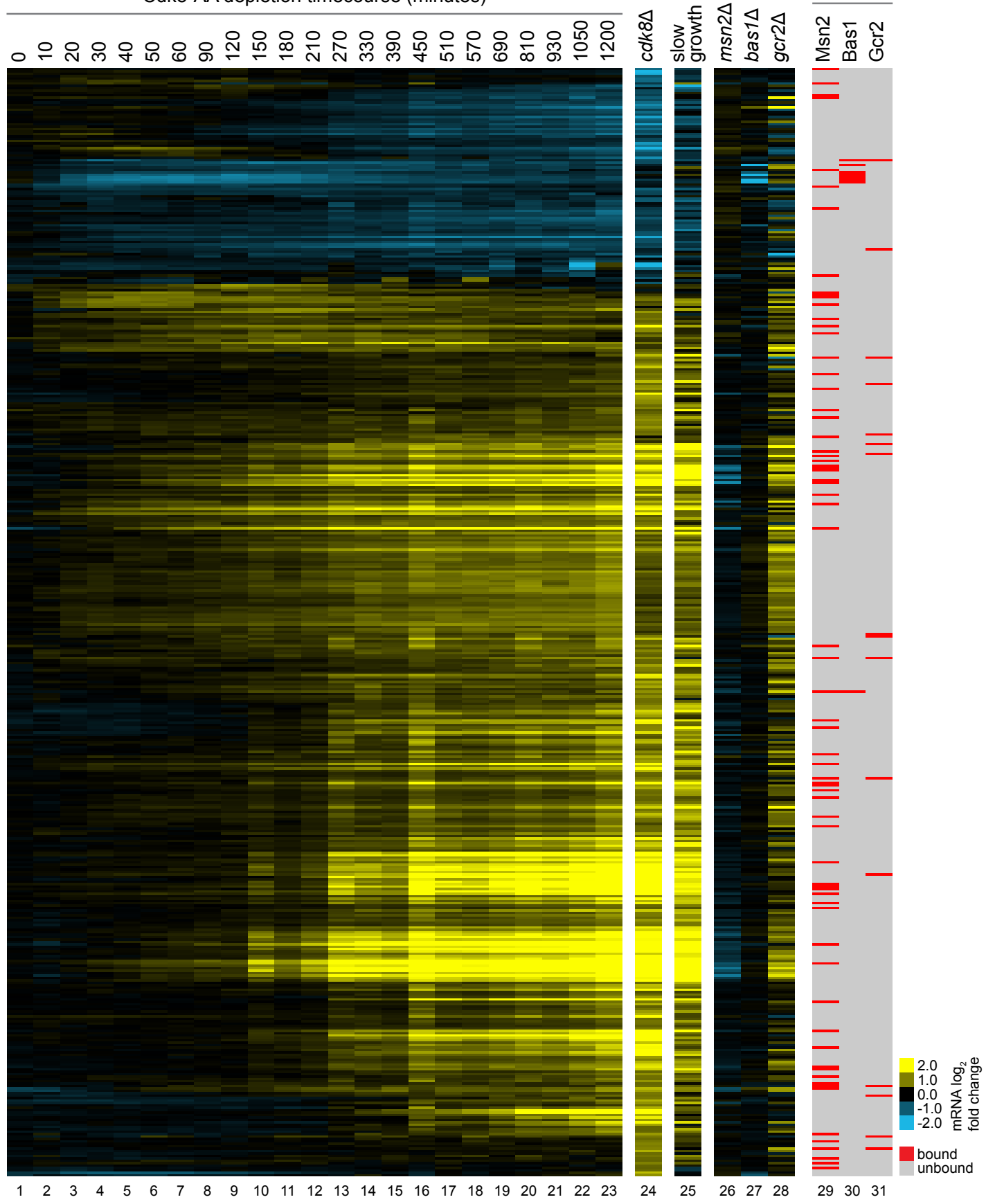


bioRxiv preprint doi: https://doi.org/10.1101/2021.03.12.435012; this version posted March 12, 2021. The copyright holder for this preprint Fiduhich was not certified by peer review) is the author/funder, who has granted bioRxiv a license to display the preprint in perpetuity. It is made

A

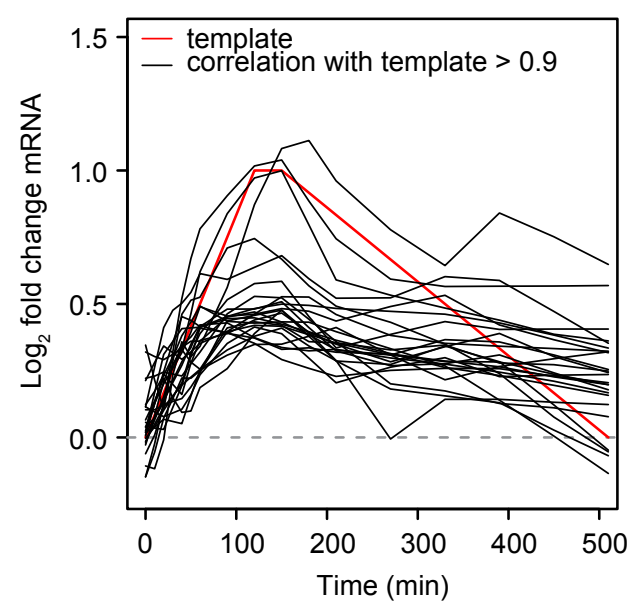

B
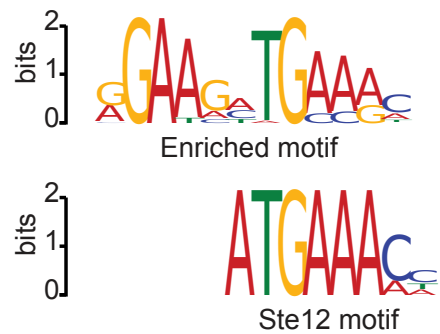

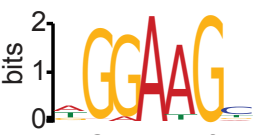

Gcr2 motif

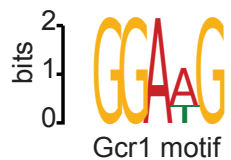

C

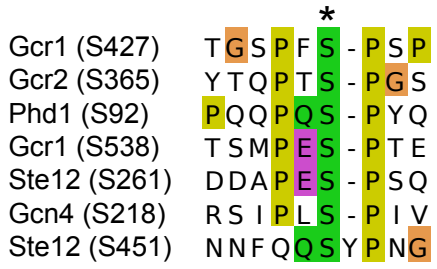

D

\begin{abstract}
Gcr2 Saccharomyces cerevisiae S288c TDEL OA00920 Torulaspora delbrueckii ZYRO0C10208p Zygosaccharomyces rouxii Kpol 400p2 Vanderwaltozyma polyspora DSM 70294 TPHA OH00870 Tetrapisispora phaffii CBS 4417 NCAS 0G01640 Naumovozyma castellii CBS 4309 NDAI OH03870 Naumovozyma dairenensis CBS 421 TBLA 0G00410 Tetrapisispora blattae CBS 6284 KAFR 0A07710 Kazachstania africana CBS 2517 KLTH0B07590p Lachancea thermotolerans NCAS 0D00270 Naumovozyma castellii CBS 4309 NDAI OF03540 Naumovozyma dairenensis CBS 421 ABL160Cp Ashbya gossypii ATCC 10895 Ecym 6443 Eremothecium cymbalariae DBVPG\#7215
\end{abstract}

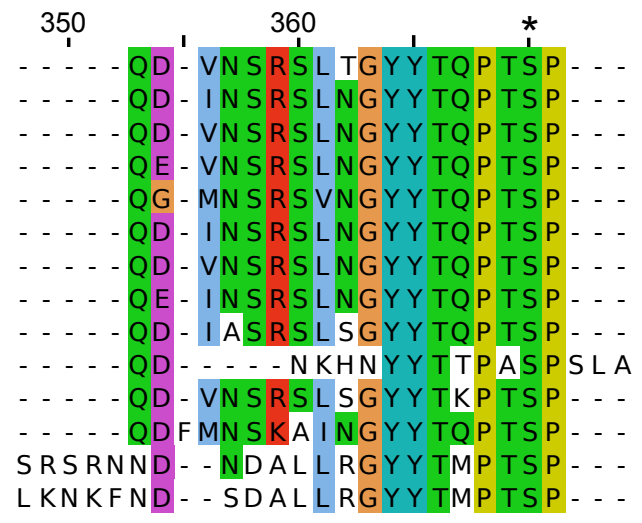

$E$

Gcr1 Saccharomyces cerevisiae S288c Kpol_1048p60 Vanderwaltozyma polyspora DSM 70294 TPHA__0I01890 Tetrapisispora phaffii CBS 4417 NDAI OI00910 Naumovozyma dairenensis CBS 421 NDAI_OE02800 Naumovozyma dairenensis CBS 421 KAFR_0E00910 Kazachstania africana CBS 2517 ZYROODD03916p Zygosaccharomyces rouxii TDEL 0B03030 Torulaspora delbrueckii FAEL245Wp Ashbya gossypii FDAG1 AEL245Wp Ashbya gossypii ATCC 10895 Ecym_7037 Eremothecium cymbalariae DBVPG\#7215 KLTHŌE12584p Lachancea thermotolerans CBS 6340 TBLA_0B04590 Tetrapisispora blattae CBS 6284 NCAS_0C02090 Naumovozyma castellii CBS 4309 FAEL308Wp Ashbya gossypii FDAG1
* 430 ATGSP'F SPS P VGE I ANNTTYPQSPST QSRSNMF SPPPSN ANVDKLTPSQT - ATTTKITKSKTKK TVTSPFSPPPDMS PGLSPFLPSPGP SGLGPFSPSPGPA L DHSAGATLKKFR LDHSAGATLKKFR - DPASNPLKKFK SPPP IGSPFKRFK MQASTQFKE I QSM - . . . . . STTF I L NPNG I KR

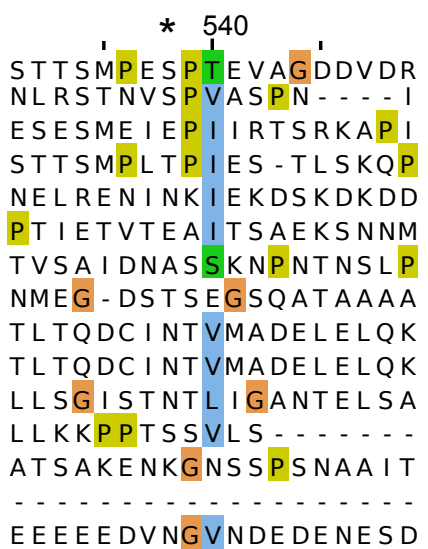


bioRxiv preprint doi: https://doi.org/10.1101/2021.03.12.435012; this version posted March 12, 2021. The copyright holder for this preprint F(nguptewas not certified by peer review) is the author/funder, who has granted bioRxiv a license to display the preprint in perpetuity. It is made

A

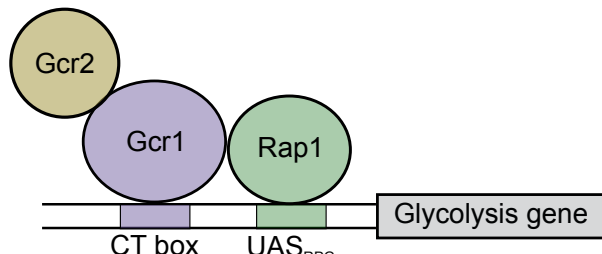

C

Gcr2

Gcr1

PYK1 promoter

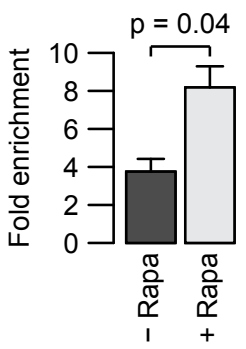

E
$\mathrm{B}$

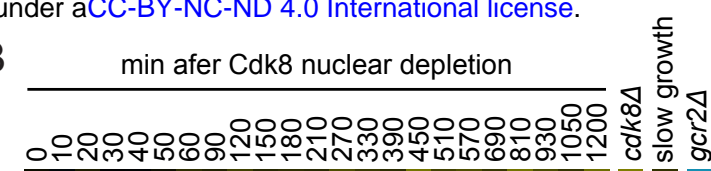

$\frac{\overbrace{0}^{\circ}}{0}$
D

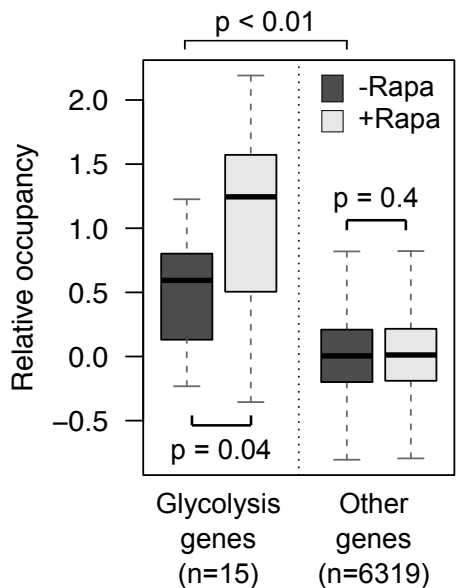

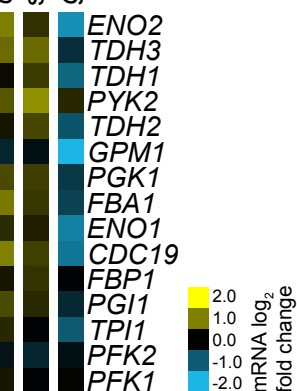

Gcr1
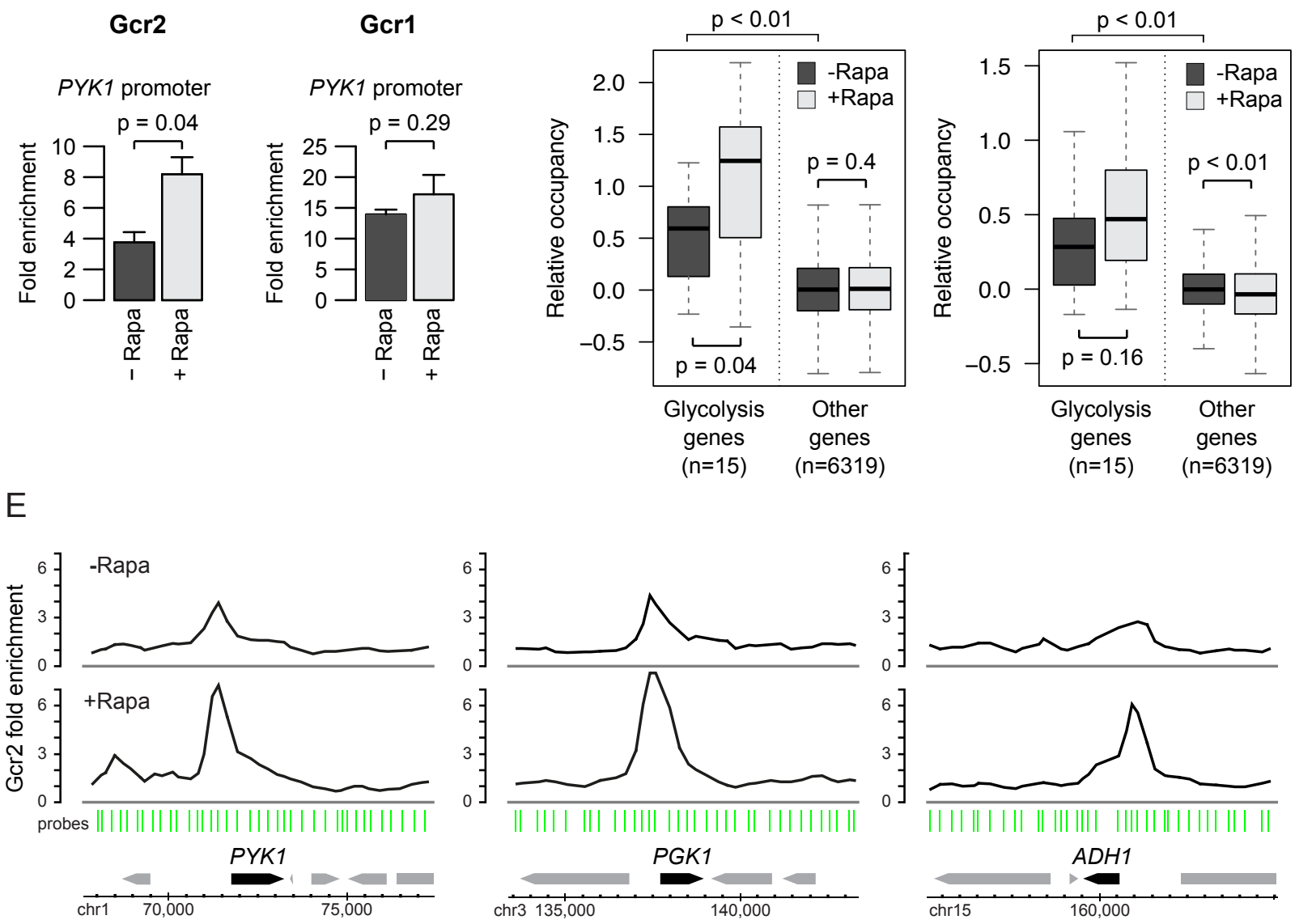
bioRxiv preprint doi: https://doi.org/10.1101/2021.03.12.435012; this version posted March 12, 2021. The copyright holder for this preprint F(nguiptewas not certified by peer review) is the author/funder, who has granted bioRxiv a license to display the preprint in perpetuity. It is made available under aCC-BY-NC-ND 4.0 International license.

A

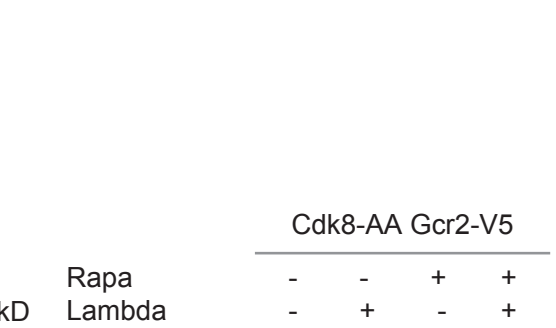

80 -

$58-$

$46-$
B

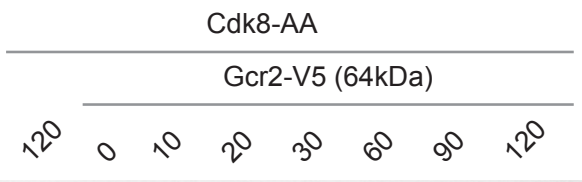

$\mathrm{kD}$

175 -

$80-$

$58-$

$46-$

$30-$

25 
bioRxiv preprint doi: https://doi.org/10.1101/2021.03.12.435012; this version posted March 12, 2021. The copyright holder for this preprint (which was not certified by peer review) is the author/funder, who has granted bioRxiv a license to display the preprint in perpetuity. It is made

Figure 5 available under aCC-BY-NC-ND 4.0 International license.

A

Substrate proteins

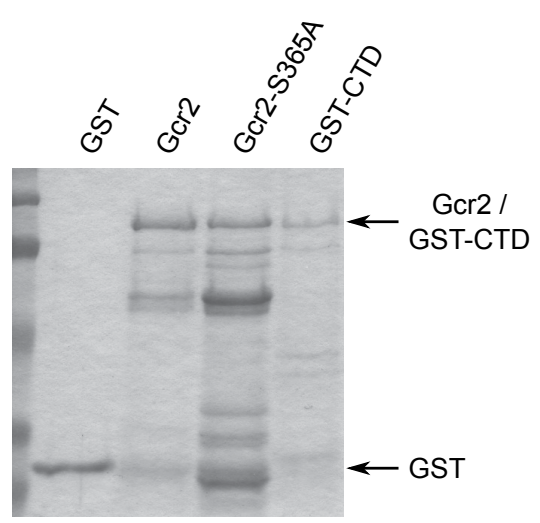

B

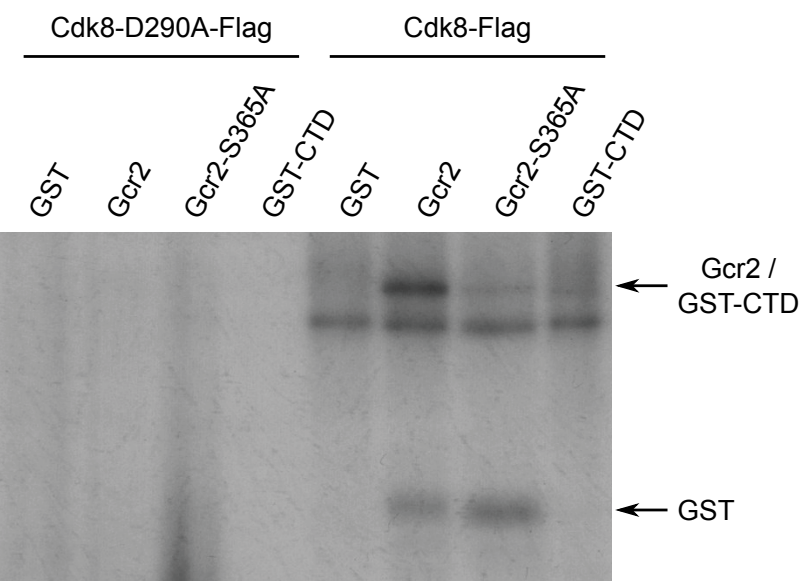

C

Gcr2 phosphopeptides

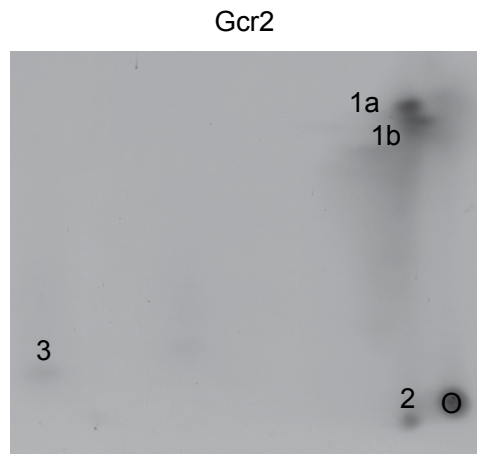

Gcr2-S365A

Charge

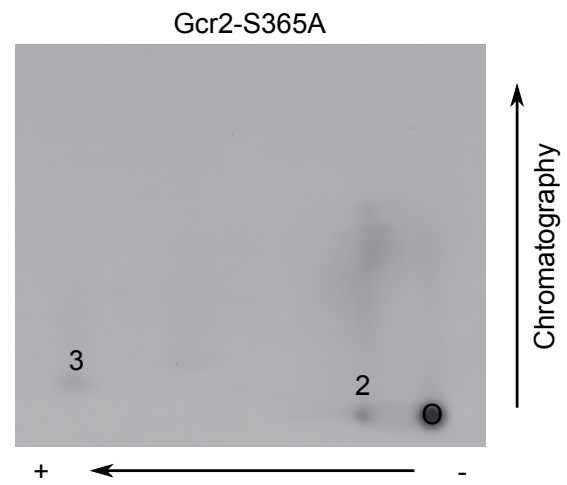


Figure 6

A bioRxiv preprint doi: https://doi.org/10.1101/2021.03.12.435012; this version posted March 12, 2021. The copyright holder for this preprint (which was not certified by peer review) is the author/funder, who has granted bioRxiv a license to display the preprint in perpetuity. It is made

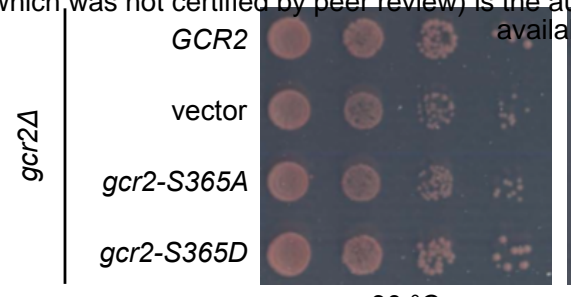

$30^{\circ} \mathrm{C}$

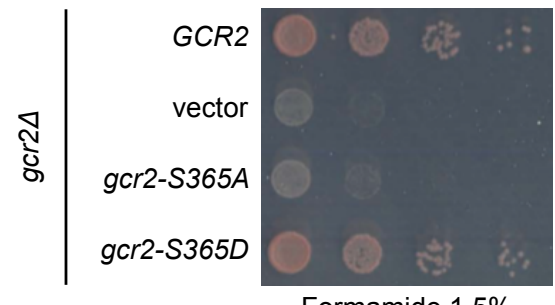

Formamide $1.5 \%$

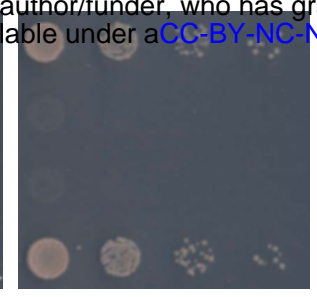

$37^{\circ} \mathrm{C}$

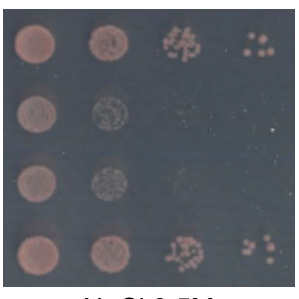

$\mathrm{NaCl} 0.5 \mathrm{M}$

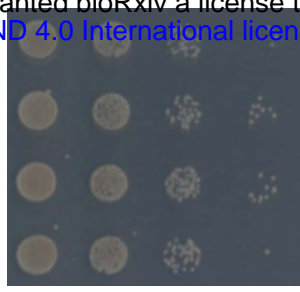

Glycerol 3\%

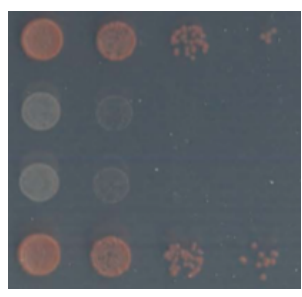

$\mathrm{HU} 25 \mathrm{mM}$

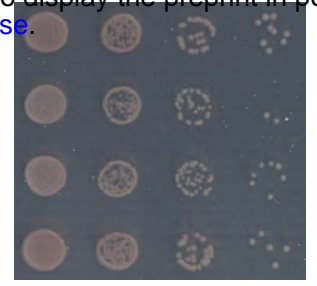

Ethanol 2\%

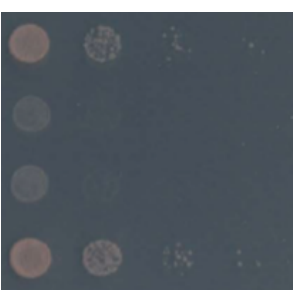

MMS $0.005 \%$
B
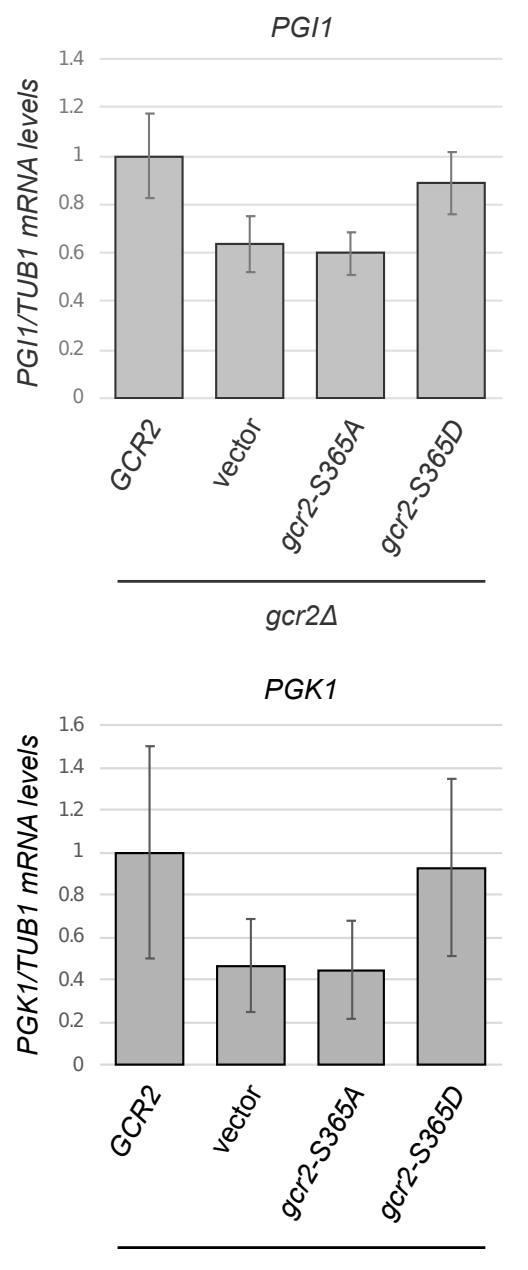

gcr2 $\Delta$
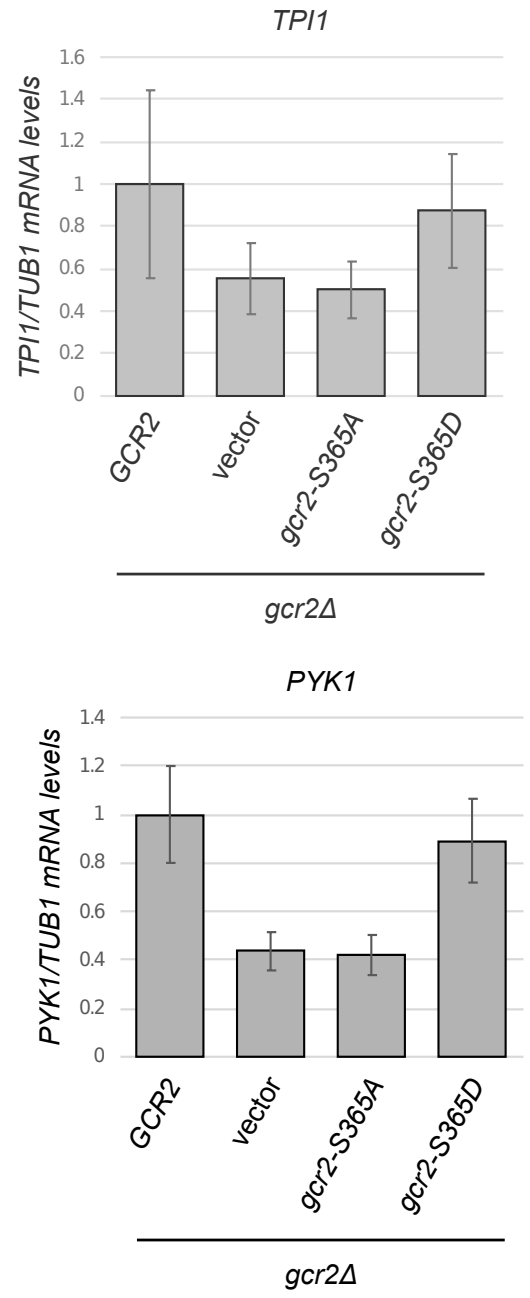

C

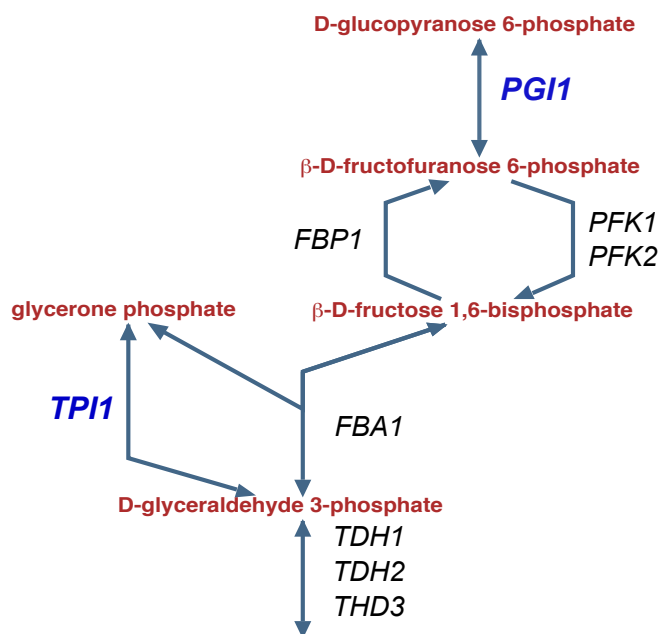

3-phospho-D-glyceroyl-phosphate

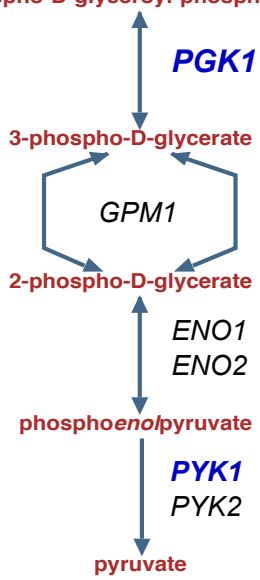


bioRxiv preprint doi: https://doi.org/10.1101/2021.03.12.435012; this version posted March 12, 2021. The copyright holder for this preprint (which was not certified by peer review) is the author/funder, who has granted bioRxiv a license to display the preprint in perpetuity. It is made Supplementary Figuraailable under aCC-BY-NC-ND 4.0 International license.

A

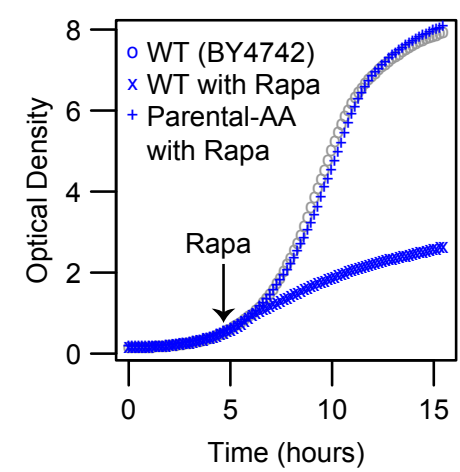

D

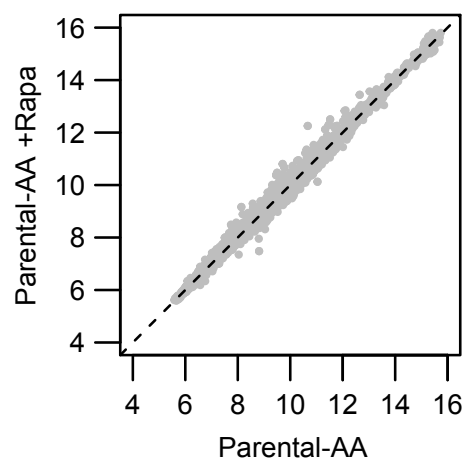

G

Cdk8-AA

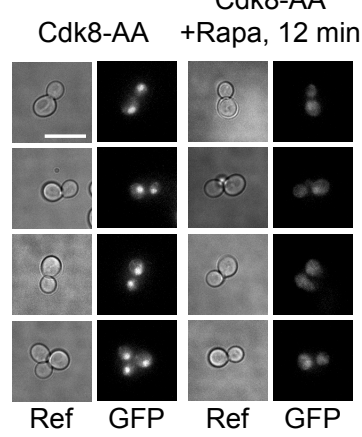

B

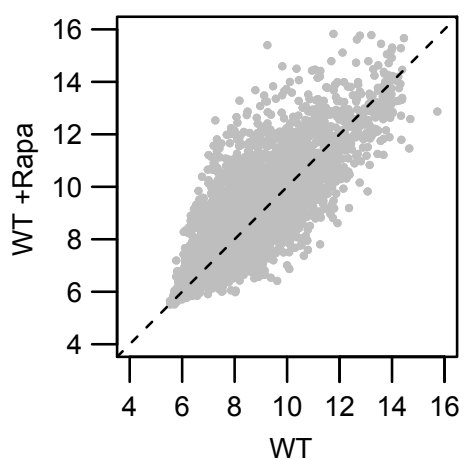

$E$

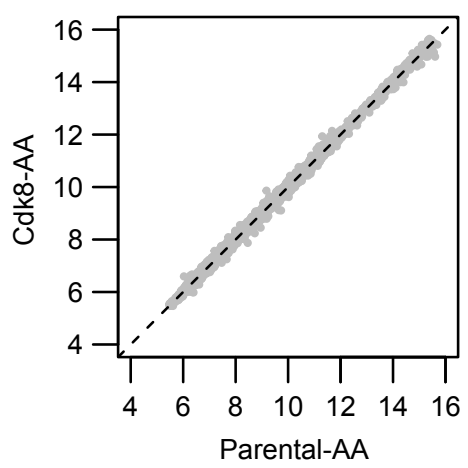

$\mathrm{H}$

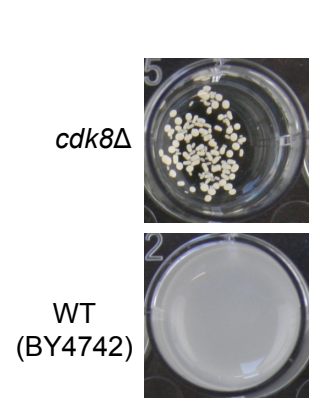

C

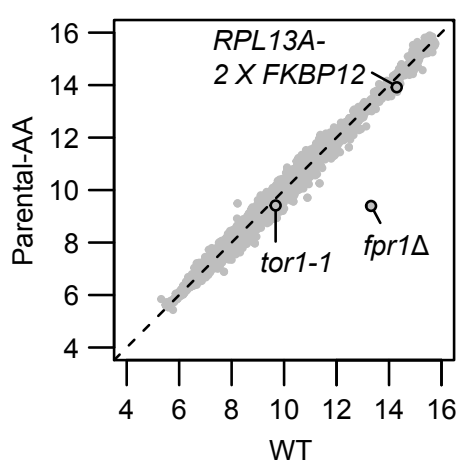

F
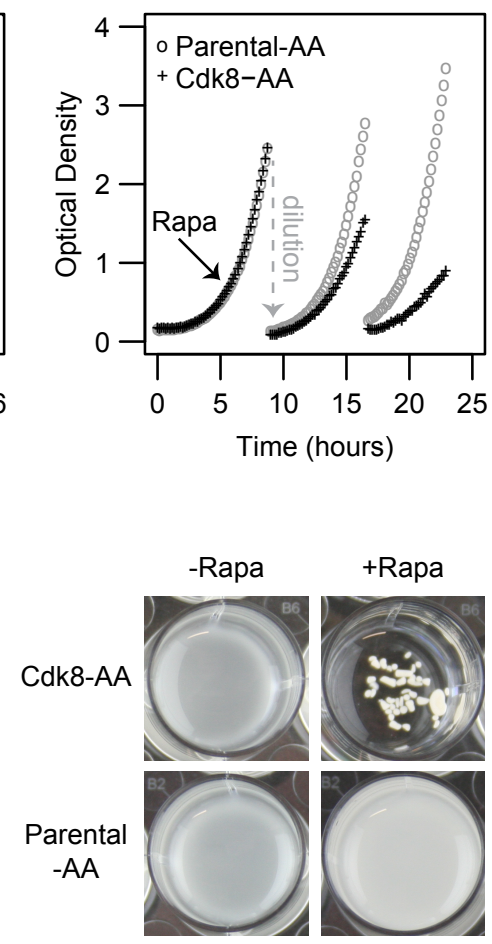